\title{
SME policies as a barrier to growth of SMEs
}

\author{
Daisuke Tsuruta
}

Accepted: 31 October 2018 / Published online: 12 November 2018

(C) Springer Science+Business Media, LLC, part of Springer Nature 2018

\begin{abstract}
We investigate whether firms have incentives to retain their status as small and medium enterprises (SMEs) to benefit from various SME policies. To examine this issue, we use the exogenous changes in the SME Basic Act in Japan. The SME Basic Act describes aims of SME policies in Japan, which involve enhancing the growth of SMEs using policy. The Act also contains the requirements and definitions of SMEs that are the target of the policies. Only firms that satisfy the definitions of SMEs under the SME Basic Act can participate in the SME policy pro-
\end{abstract}

This study was conducted as part of the Project "Study on Corporate Finance and Firm Dynamics" at the Research Institute of Economy, Trade, and Industry (RIETI). The study uses microdata from the Surveys for the Financial Statements Statistics of Corporations by Industry Houjin Kigyou Toukei Chosa conducted by the Ministry of Finance. This study was supported by a Grant-in-Aid for Scientific Research (C) \#16K03753 from the Japan Society for the Promotion of Science. The author would also like to thank Fumio Akiyoshi, Hikaru Fukanuma, Yasuo Goto, Kaoru Hosono, Daisuke Miyakawa, Masayuki Morikawa, Yoshiaki Ogura, Hiroshi Ohashi, Arito Ono, Kuniyoshi Saito, Daisuke Shimizu, Hirofumi Uchida, Iichiro Uesugi, Wako Watanabe, Peng Xu, Noriyuki Yanagawa, and Makoto Yano for many valuable comments. The seminar participants at RIETI also provided useful comments. All remaining errors are mine.

\section{Tsuruta $(\square)$}

College of Economics, Nihon University, 1-3-2 Misaki-cho,

Chiyoda-ku, Tokyo 102-8360, Japan

e-mail: tsuruta.daisuke@nihon-u.ac.jp grams in Japan. The requirements regarding capital stock in the SME Basic Act were changed in 1999. By focusing on the change in the requirements for capital stock as an exogenous event, we show that firms are less likely to increase their capital stock so that they can continue to satisfy the requirements that retain their status as SMEs. Furthermore, firms that increase their capital stock increase their size. As firms have a disincentive to increase capital stock so that they can keep their SME status, this indicates that the SME requirements are significant constraints on firm growth. Many studies show that individual SME policies (such as R\&D subsidies and public credit guarantees) stimulate firm growth and activities that are consistent with the aim of these SME policies. Although the purpose of the SME Basic Act is the enhancement of the growth of SMEs, we show that the requirements under this law impede the growth of SMEs.

Keywords SME policy · Firm growth · Equity capital $\cdot$ Small businesses

JEL Classification L53 - L25 · G32 - L26

\section{Introduction}

We investigate whether policies for small and medium enterprises (SMEs) impede incentives to graduate from SME status. Economic theories justify the use 
of SME policies when market failure occurs (Storey 1994). Berger and Udell (1998) argue that the information gap between lenders and borrowers is severe, which means that credit rationing is serious for SMEs. ${ }^{1}$ To enhance credit supply for SMEs, Mankiw (1986) argues that the government can establish public lending and credit guarantee schemes, which can improve social welfare. ${ }^{2}$ In addition, Lenihan (2011) argues that dynamic externalities (e.g., knowledge spillovers and network externalities) should be promoted by SME policies because of systemic failures. If the spillover of knowledge and innovation from $R \& D$ investment is significant, ${ }^{3}$ the benefits from innovation spread to other firms that do not pay the cost of investment. Arrow (1962) argues that the social benefits of innovation are larger than the private benefits for firms, which leads to underinvestment in $\mathrm{R} \& \mathrm{D}$. If the positive externalities relating to spillovers from innovation are significant, policy intervention for underinvestment is justified.

However, as Storey (1994) argues, the aim of actual SME policies is ambiguous from an economic viewpoint. Many SME policies exist even if they are not justified by market failures, and an excessive number of SME policies have been adopted in many countries. One of the reasons for the excessive use of SME policies is that many government departments feel that SMEs should be supported by economic policies and regard SMEs as "their responsibility" (Storey 2008). As shown in Table 1, which provides a list of SME policies compiled by the Ministry of Economy, Trade and Industry (METI) in Japan, the menu of SME policies is large. In addition to these policies, the Ministry of Finance reduces the corporate tax rate for firms that satisfy SME requirements. Often, the government implements SME policies even when market failure is not serious. For example, Table 1 shows that the program "Trade practices and public procurement" increases the opportunity for SMEs to win contracts in government offices. Because SMEs cannot always supply a higher quality of goods or services compared with large firms, SME policy should not increase their

\footnotetext{
${ }^{1}$ Some previous studies (e.g., De Meza 2002; Dawson et al. 2014) argue that under asymmetric information, firms borrow more funds compared with the situation of symmetric information.

${ }^{2}$ In Japan, the social cost of credit guarantees is also significant, as argued by Saito and Tsuruta (2018).

${ }^{3}$ Acs and Szerb (2007), for instance, argue that this is the case.
}

opportunities to win contracts because this reduces market efficiency. In addition, the corporate tax rate is reduced for all SMEs, which is another policy that is not justified by market failure. Although a public credit guarantee is justified by severe market failure as Mankiw (1986) argues, the amount of credit guarantee provided can often be excessive. OECD (2016) points out that "SMEs receive substantial government support, particularly through a large credit guarantee system, which supports about $40 \%$ of Japanese SMEs" (p. 16). ${ }^{4}$

In sum, SMEs receive substantial government support through a wide variety of SME policies and, as OECD (2016) argues, these policies can reduce incentives for SME growth. ${ }^{5}$ Firms cannot benefit from the huge range of SME policies listed in Table 1 if they outgrow their SME status and become large firms. ${ }^{6}$ In addition, if a firm graduates from an SME to a large firm, it cannot access the public credit guarantee. During periods of financial crisis (in particular, the global financial crisis in 2008), additional public credit guarantee programs commenced, which enabled SMEs to access guaranteed loans more easily, thereby enhancing their liquidity. Furthermore, large firms do not enjoy a reduced corporate tax rate; therefore, they must pay a higher rate if they graduate from SME status. Because they wish to retain their access to the various SME policies available, we predict that firms do not have the incentive to graduate from SME status, which impedes firm growth.

Many studies empirically investigate the effects of several individual SME policies. A number of studies (e.g., Kang and Heshmati 2008; Oh et al. 2009; Craig et al. 2007; Uesugi et al. 2007) show empirically that the public credit guarantee program has positive effects on employment, sales, and local growth, and that it reduces the default and bankruptcy rates

\footnotetext{
${ }^{4}$ According to OECD (2013), the volume of credit guarantees as a percentage of GDP is $7.3 \%$ in Japan, the highest among the listed countries.

${ }^{5}$ OECD (2016) notes that "small companies in Japan tend to remain small, in part because high public support discourages small firms from growing because they would lose the benefits associated with SME status" (p. 11).

${ }^{6}$ For example, the policies result in SMEs winning contracts even if their production capacity and efficiency are not as high as those of larger firms, so the policies enhance the profitability of SMEs. In other words, if firms grow from SMEs into large firms, they cannot participate in these policy programs and this reduces their opportunities to win contracts.
} 
Table 1 List of major SME policies in Japan

\author{
Management Support \\ Start-ups and ventures \\ Business innovation \\ New collaboration \\ Business revitalization \\ Employment and human resources
}

Globalization

Trade practices and public procurement

Business stability

Mutual aid system

Small businesses

Small and medium manufacturers

Technological innovation, IT, and energy efficiency

Intellectual property

SME Assistance Centers

Financial Support

Safety-net guarantee program

Safety-net loans

\section{Fiscal Support}

Taxation

Accounting

Companies Act
Assists those planning to start a business or venture owners trying to improve their operations in financing and obtaining relevant information.

Assists SMEs undergoing business innovation in financing, handling taxes, and cultivating markets.

Supports collaboration between SMEs to enter new areas of business by providing subsidies, advice, and financing assistance.

Supports SMEs in their efforts to revitalize their business through the SME Revitalization Support Committee.

Supports SMEs with human resources development and the resolution of business challenges by implementing the Small and Medium-sized Enterprise Consultants system, offering training, and dispatching experts.

Provides information and advice to help SMEs to move production overseas or find markets abroad.

Promotes fair subcontracting practices and the development of small and medium-sized subcontractors and thereby increases the opportunity for SMEs to win contracts.

Assists SMEs in maintaining stable operations by supporting them during bankruptcy, new pandemic influenza, and earthquakes and other natural disasters, as well as by assisting them to develop business continuity plans.

Helps small companies to prepare for business closure and retirement, and SMEs to prepare for the bankruptcy of their major customers.

Provides managerial and financial support to small businesses with 20 or fewer employees (five or fewer for those in the commerce or service sector).

Supports R\&D and human resources development at SMEs with key manufacturing technologies. Selects "300 of Japan's Exciting Monozukuri (Manufacturing) SMEs."

Assists SMEs committed to technological development, IT utilization, and higher energy efficiency by providing subsidies, financial assistance, and relevant information.

Supports SMEs with intellectual property strategies by implementing measures to protect intellectual property and measures to combat damage caused by counterfeiting.

Dispatches experts to assist SMEs in addressing difficult or specialized business challenges (e.g., launch of new operations or business succession) and otherwise helps SMEs directly or via support institutions.

Supports SMEs whose business stability is threatened by external factors (e.g., a major customer's restricted operations or application for rehabilitation procedures, the impact of a disaster, or the failure of the main bank) by making additional credit guarantees available.

Makes loans to SMEs temporarily facing cash flow problems owing to a radical change in the business environment, the bankruptcy of a major customer, or the streamlining of the main bank.

Gives information and advice on various tax measures to support SMEs.

Gives information and advice on "SME accounting," which helps SMEs to enhance their capability to analyze management, ensure financing, and increase order intake.

Gives information and advice on the new Companies Act, which additionally includes systems that bring significant benefits to SMEs, such as the accounting adviser system. 
Table 1 (continued)

\begin{tabular}{ll}
\hline Business succession & $\begin{array}{l}\text { Gives information and advice on measures to support SMEs' smooth } \\
\text { business succession. }\end{array}$ \\
$\begin{array}{l}\text { Commerce and Regional Support } \\
\text { Revitalization of commerce }\end{array}$ & $\begin{array}{l}\text { Supports efforts to improve the attractiveness of small and medium mer- } \\
\text { chants, shopping districts, and city centers. } \\
\text { Invigorates regional industries, such as locally based industries and tradi- } \\
\text { tional handicraft industries, by providing subsidies and low-interest loans. } \\
\text { Regional industries }\end{array}$ \\
$\begin{array}{l}\text { Comprehensively assists business activities conducted by organic partner- } \\
\text { ships between SMEs and those engaged in agriculture/forestry/fisheries } \\
\text { through the effective use of their business resources. }\end{array}$ \\
Actively supports and increases the publicity for attractive regional prod- \\
"Meet and Experience Regional
\end{tabular}

Source: Website of the Small and Medium Enterprise Agency (http://www.chusho.meti.go.jp/sme_english/outline/04/01.html)

Note: This table shows the list of SME policies implemented by the Ministry of Economy, Trade and Industry (METI) in Japan

of SMEs. Focusing on the R\&D policy, many studies (e.g., Cantner and Kösters 2012; Czarnitzki and Delanote 2015; Cowling 2016; Lokshin and Mohnen 2012; Koga 2005) investigate the effects of R\&D tax credits and subsidies on R\&D investment and innovation of SMEs, which are common policies for addressing the underinvestment problem. Some studies (e.g., Foreman-Peck 2013; Cin et al. 2017) focus on the policy effects of R\&D tax credits and subsidies on firm growth or productivity of SMEs. Other studies (e.g., Bernini and Pellegrini 2011; Cerqua and Pellegrini 2014; Ipinnaiye et al. 2017) argue that public subsidies (not limited to R\&D subsidies) enhance the growth of SMEs or regional firms. Some papers investigate the effects of location-based tax incentives on the growth of regional firms. Location-based taxes are used to stimulate the growth of regional firms in many countries, which aims at the regional development of less-developed areas through policy intervention by local governments. Hanson and Rohlin (2011) and Chaurey (2017) show empirically that firm growth can be enhanced in the target areas, which is the aim of the policy.

Although a number of reports focus on the effects of individual SME policies, few studies investigate whether the substantial government support for SMEs provides an incentive to retain SME status, which has a negative effect on firm growth. In this paper, we

Table 2 Definition of SMEs under the Corporation Tax Act and the SME Basic Act in Japan

Panel A: Definition under the Corporation Tax Act

$\begin{array}{lll} & \text { Capital } & \\ \text { Industry } & \text { Stock } & \text { Employees } \\ \text { All } & 100 \text { million or less } & \text { No requirement }\end{array}$

Panel B: Definition under the SME Basic Act

\begin{tabular}{|c|c|c|c|c|c|}
\hline & & \multicolumn{2}{|l|}{ Before 1999} & \multicolumn{2}{|l|}{ After 2000} \\
\hline & & Capital & & Capital & \\
\hline & Industry & Stock & Employees & Stock & Employees \\
\hline Definition 1 & Manufacturing, etc. & 100 million or less & 300 or fewer & 300 million or less & 300 or fewer \\
\hline Definition 2 & Wholesale & 30 million or less & 100 or fewer & 100 million or less & 100 or fewer \\
\hline Definition 3 & Retail & 10 million or less & 50 or fewer & 50 million or less & 50 or fewer \\
\hline Definition 4 & Service & 10 million or less & 50 or fewer & 50 million or less & 100 or fewer \\
\hline
\end{tabular}

Note: This table shows the definitions of SMEs under the Corporation Tax Act (in Panel A) and the SME Basic Act (in Panel B). "Manufacturing, etc." includes all industries except the wholesale, retail, and service industries 
investigate whether the various SME policy programs in Japan impede the growth of firms from SMEs to large firms. To examine this issue, we employ two strategies. First, we focus on the definitions of SMEs under the Corporation Tax Act, which defines SMEs as firms with capital stock of 100 million yen or less. We investigate whether SMEs that are close to this cap for capital stock (i.e., 100 million yen) are less likely than other firms to increase their capital stock so that they can remain an SME and retain their access to the SME policy programs.

Second, for our analysis, we use the changes in the Small and Medium-sized Enterprise Basic Act (the SME Basic Act) in Japan that came into effect in December 1999. The SME Basic Act is the law that establishes the basic principles and aims of SME policies in Japan, but does not describe the content of individual SME policies. This law describes the aim of SME policies as the development of the Japanese economy through the achievement of significant growth of SMEs using SME policies. The law also describes the definition and requirements of the SMEs that are the targets of the SME policies in Japan. In Japan, only firms that satisfy the definition of SMEs under the SME Basic Act can participate in the SME policy programs listed in Table 1. Before 1999, SMEs were defined as firms with 100 or fewer regular employees or with 100 million yen of capital stock or less (except for firms in the wholesale, retail, and service industries). Following revision of the SME Basic Act, the requirement for capital stock was changed to 300 million yen or less, so that firms could increase capital stock but still satisfy the requirements of the SME Basic Act. As Table 2 shows, the definitions of SMEs differ for firms in the wholesale, retail, and service industries.

By focusing on the change of the SME Basic Act as an exogenous event, we can test whether firms have incentives to retain their SME status even if they can graduate to large firm status. Firms that did not graduate from SME status when they could have are likely to have increased their capital stock after the change in the SME Basic Act, which relaxed the capital stock requirement. Furthermore, by focusing on the difference in the requirements for SMEs between industries, we can test the hypothesis using the difference-indifferences approach. As Table 2 shows, the capital stock requirement changed from 100 million yen or less to 300 million yen or less for a firm in a manufacturing industry with the change in the SME Basic Act. However, in the wholesale, retail, and service industries, this change in the capital stock requirement was not adopted either before or after the change in the SME Basic Act. Therefore, we can use the subsample of firms in the wholesale, retail, and service industries as a control group and those in the other industries as a treatment group.

Similarly, by focusing on the changes in the capital stock requirements for the wholesale industry (changed from 30 million yen or less to 100 million yen or less) and those for the retail and service industries (changed from 10 million yen or less to 50 million yen or less), we can use firms in those industries as a treatment group. As these changes in the capital stock requirement were not adopted in the other industries, we can use a subsample of firms in other industries as a control group. These heterogeneous changes in the definition of SMEs are rarely adopted in other countries, so the Japanese case is an ideal natural experiment to test the hypothesis.

The main findings of this paper are as follows. First, firms with capital stock of 100 million yen or less (i.e., SMEs according to the definitions in the Corporation Tax Act and the SME Basic Act before it was altered in 1999) are less likely to increase capital stock compared with firms with capital stock of over 100 million yen. This implies that SMEs have a disincentive to increase their capital stock because they benefit from keeping their SME status.

Second, before the change in the definition of SMEs under the SME Basic Act in 1999, a firm increased its capital stock less if the firm's capital stock was close to the capital stock requirement under the original SME Basic Act. After the change in the definition, which involved an increase in the capital stock limit, firms that satisfied the previous SME requirement then increased their capital stock. This effect is larger if a firm's capital stock is close to the capital stock requirement under the original SME Basic Act. These effects are robust because they are supported if we estimate them using a different treatment group. Furthermore, the distributions of capital stock after the policy change are right-shifted compared with those without the policy change. These impacts are large for firms with capital stock close to 100 million yen that are larger SMEs.

Third, firms that increased their capital stock also increased their firm size (in terms of asset growth). 
As firms have a disincentive to increase their capital stock so that they can keep their SME status, this indicates that the SME requirements are significant constraints on firm growth. The mitigation of the requirements of SMEs enhanced asset growth for manufacturing industries by $0.149 \%$ on average, while the actual average percentage asset growth was $1.932 \%$ from 2000 to 2007 . Additionally, we show that firms decreased their debt by increasing their equity. This implies that firms were able to adjust to an optimal capital structure after the relaxation of their capital stock requirements.

This study differs from those that focus on several SME policies. Previous work shows that each individual policy enhanced the growth of SMEs, which is consistent with the aim of those policies. The SME policy that we study in Japan aims to promote the development of small businesses. ${ }^{7}$ Although the aim of the policy is the growth of SMEs, we show that the SME policy impeded firm growth of small businesses through decreases in equity capital.

Our study is related to work that uses the calibration of a theoretical model to argue that policies that depend on firm size cause distortions of firm size. For example, Garicano et al. (2016) and Gourio and Roys (2014) focus on the many labor laws in France that are binding for firms with 50 employees or more and estimate the welfare costs of these regulations. Using the Lucas model, Guner et al. (2006) and Guner et al. (2008) show that size-dependent laws, such as Japan's Large Scale Retail Location Law, distort firm-size distributions. García-Santana and Pijoan-Mas (2014) focus on the Small Scale Reservation Laws in India that reserve several products for production by smallscale industries. They also use the Lucas model to show that this policy decreases average output per worker by $2 \%$ in the economy. Hosono et al. (2017) investigate whether the distribution of firm size is distorted using the SME Basic Act in Japan.

Similarly to these studies, we find that sizedependent policies impede firm growth by small businesses. However, this paper differs from the existing literature in two ways. First, whereas previous work employs simulations from theoretical models, we employ a difference-in-differences approach using the change in the SME Basic Act as an exogenous

\footnotetext{
${ }^{7}$ See http://www.chusho.meti.go.jp/soshiki/ninmu.html regarding the aim of the Small and Medium Enterprise Agency in Japan.
}

event and utilize not a macroeconomic model but an econometric model, using firm-level data of small businesses. Second, we focus not only on firm growth, but also on the financial activities of small businesses. ${ }^{8}$

The remainder of the paper is organized as follows. Section 2 provides the definitions of SMEs under the Corporation Tax Act and the SME Basic Act. Section 3 describes the data set. Section 4 introduces the empirical strategy and hypotheses for the relationships between SME policies, capital stock, and firm growth. Section 5 provides the estimation results for the hypotheses. Section 6 concludes the paper.

\section{Definitions of SMEs in Japan}

\subsection{Corporation Tax Act}

There are several definitions of SMEs in Japan, with the major definitions being those of the SME Basic Act and the Corporation Tax Act. Under the Corporation Tax Act, SMEs are defined as firms with 100 million yen of capital stock or less (Panel A of Table 2). The corporate tax rate is reduced for firms that satisfy the definition of an SME under the Corporation Tax Act. For example, the corporate tax rate for SMEs is $22 \%$, which is applied to incomes under eight million yen. The corporate tax rate for large firms between 1999 and 2012 was 30\%. ${ }^{9}$ Therefore, if firms

\footnotetext{
${ }^{8}$ Hosono et al. (2017) also investigate the effects of changing the SME Basic Act of Japan using firm-level data. However, the data used in Hosono et al. (2017) include firms with 30 million yen or more of capital stock, and therefore do not contain the data of smaller-sized SMEs. Our data include various-sized SMEs, so we can investigate the effects on micro firms that need the support of SME policies. According to Economic Census for Business Frame in 2014 by the Statistics Bureau of the Ministry of Internal Affairs and Communications (MIC), the ratio of the number of firms with 30 million yen or less of capital stock to all firms is $86.7 \%$ (see the website of the MIC (http://www.stat.go.jp/data/e-census/2014/pdf/kaku_gaiyo.pdf [last date accessed: September 2018]) for more detail), so we can investigate the effects of the SME Basic Act more accurately. However, the data used in Hosono et al. (2017) are panel data, not pooled cross-section data, and can therefore investigate the effects on the postperformance of SMEs over several years.

${ }^{9}$ See the website of the Ministry of Finance in Japan (https://www. mof.go.jp/tax_policy/summary/corporation/082.pdf (in Japanese, last date accessed: September 2018)) regarding the corporate tax rate trends.
} 
satisfy the definition of an SME under the Corporation Tax Act, they can pay a low corporate tax rate and increase their cash flow.

\subsection{SME Basic Act}

The SME Basic Act was implemented in 1963. The aim of this law is "to promote in a comprehensive manner measures for small and medium enterprises by establishing the basic principles, basic policies and other basic matters relating to measures for SMEs and clarifying the responsibilities, etc. of the State and of local public entities, so as to contribute to the sound development of the national economy and improvement in the quality of life of the people." To realize this aim, this law establishes "the basic principles, basic policies and other basic matters relating to measures for SMEs". ${ }^{10}$

This law does not describe the contents of individual SME policies. Instead, it describes the basic principles and purpose of SME policies in Japan, which relate to the development and growth of SMEs. Article 3, Basic Principles notes that the "development of SMEs must be encouraged by promoting business innovation and start-ups among them, strengthening their business fundamentals, and smoothing their adaptation to changes in social or economic conditions so as to foster the autonomous efforts of independent SMEs."11 In sum, this law aims to develop the Japanese economy through the encouragement of the growth of SMEs using various SME policies.

The key part of this law is the definition and requirement of SMEs that are used in the SME policies of the Small and Medium Enterprise Agency. This law determines the target firms of SME policies by defining the requirements of firms to be classified as "SMEs". This requirement is adopted in almost all policies implemented by the Small and Medium Enterprise Agency, so firms that satisfy the requirement of the SME Basic Act can utilize individual SME policies.

\footnotetext{
${ }^{10}$ See Article 1 on the website of the Small and Medium Enterprise Agency (http://www.chusho.meti.go.jp/sme_english/ outline/08/01_01.html) (last date accessed: September 2018) .

${ }^{11}$ See Article 3 on the website of the Small and Medium Enterprise Agency (URL is in footnote 10).
}

As shown in Panel B of Table 2, the definition of SMEs in the SME Basic Act is complex. The definitions of SMEs before December 1999 are as follows. i) SMEs under the SME Basic Act are defined as firms with 100 million yen of capital stock or less and/or 300 or fewer regular employees. ii) SMEs in the wholesale industry are defined as firms with 30 million yen of capital stock or less and/or 100 or fewer regular employees. iii) SMEs in the retail industry and the service industry are defined as firms with 10 million yen of capital stock or less and/or 50 or fewer regular employees.

In December 1999, the SME Basic Act was revised and the capital stock requirement was relaxed. The revised requirement for SME status after December 1999 is as follows. i) SMEs under the SME Basic Act are defined as firms with 300 million yen of capital stock or less and/or 300 or fewer regular employees. ii) SMEs in the wholesale industry are defined as firms with 100 million yen of capital stock or less and/or 100 or fewer regular employees. iii) SMEs in the retail industry are defined as firms with 50 million yen of capital stock or less and/or 50 or fewer regular employees. iv) SMEs in the service industry are defined as firms with 100 million yen of capital stock or less and/or 100 or fewer regular employees.

According to Nakata (2013), the main reasons for relaxing the capital stock requirements are as follows. First, the original requirement for the capital stock was established in 1963, which is not consistent with Japan as a developed country. Second, personal guarantees by business owners were required to borrow funds from banks for over half of the firms with a capital stock of 300 million yen or less. In contrast, if firms' capital stock was over 300 million yen, personal guarantees by business owners were rarely required. Third, the number of public firms with 300 million yen of capital stock or less was small, while the number of firms with over 300 million yen was large. This implies that credit constraints were more severe for firms with 300 million yen of capital stock or less, so the capital stock requirement was relaxed.

\section{Data}

We use annual firm-level data from the Surveys for the Financial Statements Statistics of Corporations by Industry (hereafter FSSC; Houjin Kigyou Toukei 
Chosa in Japanese) conducted by the Ministry of Finance. According to the website of the Ministry of Finance, ${ }^{12}$ the FSSC are "one part of the fundamental statistical surveys under the Statistics Act and have been conducted as sampling surveys so as to ascertain the current status of business activities of commercial corporations in Japan." The target firms of the FSSC are all commercial corporations in Japan. All firms with capital stock of 600 million yen or more are included. Those with capital stock of between 100 million and 600 million yen are randomly selected with equal probability. Those with less than 100 million yen of capital are randomly sampled every fiscal year. Therefore, of the firms with less than 100 million yen in capital, a different sample of target firms is selected each fiscal year. The response rates for each fiscal year are around $80 \%$. The questionnaire forms are available at the Ministry of Finance (MOF) website. ${ }^{13}$ A list of all variables is available from this website. ${ }^{14}$

Data on firms' balance sheets are available at the beginning and end of each fiscal year. The data at the end of fiscal year $t$ are set equal to the data at the beginning of fiscal year $t+1$. We use observations from FY1991 to FY2007. To exclude large firms, the sample is limited to firms with 500 million yen or less of capital stock. We choose the sample period FY1991-FY2007 to exclude the effects of the bubble economy before 1990 and the global financial crisis after 2008. The number of full firm-year observations is 306,353 during the period FY1991-FY2007. ${ }^{15}$

\footnotetext{
${ }^{12}$ For details of the survey see: https://www.mof.go.jp/english/ pri/reference/ssc/index.htm (last date accessed: September 2018).

${ }^{13}$ https://www.mof.go.jp/pri/reference/ssc/outline.htm\# questionnaire (in Japanese, last date accessed: September 2018).

${ }^{14}$ The items in the annual survey are similar to those in the quarterly survey. All quarterly items in English are available at the following website: https://www.mof.go.jp/english/ pri/reference/ssc/historical.htm (last date accessed: September 2018).

${ }^{15}$ The database in this paper is pooled-cross section data, so the entry-exit data are unavailable. The observations are randomly selected in every year, so firms that are likely to exit are included in our sample. This implies that sample selection bias is not so severe. However, we cannot control remaining sample selection bias using econometric models, which is a shortcoming of our database.
}

\section{Empirical strategy}

\subsection{Effects of the cap on capital stock}

\subsubsection{Hypothesis}

As argued by Baumol (1962), firms determine the growth rate that maximizes the net revenue and cost of growth. Without a cost of growth (i.e., the administrative cost of growth), firms have an incentive to grow infinitely. However, the cost of growth is significant, so an optimal growth rate exists. In general, public support lowers the cost of growth for SMEs, so SME policy could stimulate firm growth and increase the number of firms transitioning from a SME to a large firm. If they do not satisfy the requirements of SME status, the cost of growth increases discontinuously because they cannot receive public support and reduced corporate tax. ${ }^{16}$ Therefore, the growth rates of firms are lower after transition from SME status.

Firms cannot receive public support, however, if they grow and transition from SME status. In this case, the cost of firm growth, which includes the opportunity cost of receiving SME policies, is higher for firms near to the cap of the requirements of SMEs. After transition from SME status, the cost of firm growth does not include the opportunity cost, so the optimal growth rate increases.

In sum, when the positive effects of public support of firm growth or the benefit of being a large firm are large, the growth rate of SMEs is not lower, even though firms are close to the capital limit for being classified as an SME. In this case, the SME policy is not a significant barrier to firm growth. However, if the opportunity cost of receiving SME policies is large, the growth rate of those SMEs is lower. In this case, the SME policy is a significant barrier to firm growth. We need to test which cases are supported using empirical analysis.

As described in the previous section, the cap on capital stock in the definition of SMEs under the Corporation Tax Act is 100 million yen. If firms have an incentive to retain their SME status and observe the SME requirements to save corporate tax, they will not increase their capital stock over 100 million yen. We

\footnotetext{
${ }^{16}$ This is an upward shift in the cost of growth in Figure 1 of Baumol (1962) when public support is terminated or tax rates rise.
} 
Table 3 Definitions of capital stock dummy

\begin{tabular}{|c|c|c|c|}
\hline Dummy variable & Definition & $\mathrm{N}$ & Mean \\
\hline Capital Stock 20M & equals one if a firm's capital stock is $>10-20$ million yen & 26,499 & 0.087 \\
\hline Capital Stock 30M & equals one if a firm's capital stock is $>20-30$ million yen & 18,839 & 0.062 \\
\hline Capital Stock 40M & equals one if a firm's capital stock is $>30-40$ million yen & 8,334 & 0.027 \\
\hline Capital Stock 50M & equals one if a firm's capital stock is $>40-50$ million yen & 17,455 & 0.057 \\
\hline Capital Stock 60M & equals one if a firm's capital stock is $>50-60$ million yen & 4,680 & 0.015 \\
\hline Capital Stock 70M & equals one if a firm's capital stock is $>60-70$ million yen & 2,954 & 0.010 \\
\hline Capital Stock 80M & equals one if a firm's capital stock is $>70-80$ million yen & 4,839 & 0.016 \\
\hline Capital Stock 90M & equals one if a firm's capital stock is $>80-90$ million yen & 3,783 & 0.012 \\
\hline Capital Stock 100M & equals one if a firm's capital stock is $>90-100$ million yen & 16,422 & 0.054 \\
\hline Capital Stock 110M & equals one if a firm's capital stock is $>100-110$ million yen & 1,857 & 0.006 \\
\hline Capital Stock 120M & equals one if a firm's capital stock is $>110-120$ million yen & 2,719 & 0.009 \\
\hline Capital Stock 130M & equals one if a firm's capital stock is $>120-130$ million yen & 1,540 & 0.005 \\
\hline Capital Stock 140M & equals one if a firm's capital stock is $>130-140$ million yen & 1,447 & 0.005 \\
\hline Capital Stock $150 \mathrm{M}$ & equals one if a firm's capital stock is $>140-150$ million yen & 4,101 & 0.013 \\
\hline Capital Stock 200M & equals one if a firm's capital stock is $>150-200$ million yen & 14,155 & 0.047 \\
\hline Capital Stock 300M & equals one if a firm's capital stock is $>200-300$ million yen & 22,918 & 0.075 \\
\hline Capital Stock 400M & equals one if a firm's capital stock is $>300-400$ million yen & 18,626 & 0.061 \\
\hline Capital Stock 500M & equals one if a firm's capital stock is $>400-500$ million yen & 26,540 & 0.087 \\
\hline
\end{tabular}

Note: This table shows the definitions of Capital Stock Dummies used in Table 5

predict that firms with a capital stock close to 100 million yen are less likely to increase their capital stock if the requirements are a significant constraint. In addition, under the SME Basic Act, the caps on capital stock in the definitions of SMEs are 10,30,100, or 300 million yen, depending on the industry and the year. We predict that firms with a capital stock close to these caps are less likely to increase their capital stock. However, as we argued, if SME policies reduce the cost of firm growth significantly and the opportunity cost of SME policy is negligible, the estimated effects of these caps are insignificant.

\subsubsection{Equation}

To test our hypothesis, we estimate the following equation:

$$
\begin{aligned}
\Delta \text { Capital Stock }_{i, t}= & \sum \alpha_{1}^{j} \text { Capital Stock Dummy } y_{i, t-1}^{j} \\
& +\mathbf{X}_{i, t} \alpha_{2}+\zeta_{t}+\eta_{i}+\theta_{i, t}
\end{aligned}
$$

where $\theta_{i, t}$ is the error term of firm $\mathrm{i}$ in fiscal year $\mathrm{t}, \eta_{i}$ is industry fixed effects of 45 industries, and $\zeta_{i}$ is year fixed effects from FY1991 to FY2007. We use two definitions of $\Delta$ Capital Stock $_{i, t}$. One is a dummy variable that has a value of one if capital stock at the end of fiscal year $t$ is larger than at the beginning of fiscal year t (additional capital stock dummy, shown as "Dummy" in tables). The other is the difference in capital stock at the end of fiscal year $t$ compared with that at the beginning of fiscal year $t$ (amount of $\Delta$ capital stock, shown as "Amount" in tables). $\mathbf{X}$ includes leverage at the beginning of fiscal year $t$, tangible fixed assets at the beginning of fiscal year $t$, and operating incomes in fiscal year $\mathrm{t}$.

We drop observations where there is a decrease in the capital stock because there is only a very small number of such observations. The percentage of observations where there is a decrease in capital stock is $0.74 \%$, while that with an increase in capital stock is $4.67 \%$ and that with unchanged capital stock is $94.59 \%$. Furthermore, the distribution of $\Delta$ Capital Stock is complicated if we include the observations with a decreasing capital stock. This is because most firms did not change their capital stock. Therefore, to focus on the firms that increased their capital stock, 
we do not use observations for which the capital stock decreased. By dropping the observations where the capital stock decreased, we can apply a tobit model to estimate the policy effects of the cap on the capital stock.

We focus on the effects of 18 types of Capital Stock Dummy at the end of fiscal year t-1. The definitions of each dummy variable are shown in Table 3. If firms have an incentive to satisfy the SME requirements under the Corporation Tax Act and the SME Basic Act, firms with capital stock close to 100 million yen are less likely to increase their capital stock. Therefore, in this case, the coefficient of capital stock $100 \mathrm{M}$ is negative. In addition, compared with the effects of the capital stock $110 \mathrm{M}$ dummy and capital stock dummies for similar amounts, the magnitudes of the negative effects should be larger. Similarly, the caps of 30 and 300 million yen under the SME Basic Act have significant effects on additional capital stock, and are both negative. On the other hand, these effects are not significant if the constraint caused by the requirement is not severe.

According to $\mathrm{Ou}$ and Haynes (2006), funds for acquiring additional equity capital in SMEs are determined by firm age, size, sales growth, financial condition, internal financial sources (such as owner loans or personal and business credit cards), and loans with traditional or nontraditional institutions. We use leverage, cash holdings, tangible fixed assets, operating incomes, total factor productivity, and year and industry dummies as control variables. We do not employ firm size because this is highly correlated with Capital Stock Dummy. Leverage is a proxy for financial condition and loans with traditional or nontraditional institutions. Highly leveraged firms have easier access to loans from traditional or nontraditional institutions. On the other hand, very highly leveraged firms are financially distressed firms (as argued by Opler and Titman 1994), so leverage is also a proxy for financial condition. Because highly leveraged firms have incentives to increase equity capital to mitigate their financial distress, we predict that leverage has positive effects on additional equity capital. Leverage is defined as the book value of debt divided by the book value of assets at the beginning of fiscal year t. Cash holdings are a proxy for liquidity. We predict that firms with higher liquidity are less risky, so the effects on additional registered equity are positive. Cash holdings are defined as cash holdings at the beginning of fiscal year $t$, normalized by total assets at the beginning of fiscal year $t$.

Operating incomes are a proxy for financial condition. High operating incomes suggest that firms have sufficiently high cash flows, which leads to low credit constraints. In addition, operating incomes are a proxy for firm profitability. If firms with low cash flows face credit constraints on bank loans and use additional equity capital, then the coefficient of operating incomes will be negative. On the other hand, if profitable firms can use additional equity, the coefficient of operating incomes will be positive. Operating income is defined as operating income in fiscal year $\mathrm{t}$, normalized by total assets at the beginning of fiscal year $t$. Tangible fixed assets are variables representing the amount of collateral assets. Firms with high collateral assets are less risky and have easier access to loans. Therefore, tangible fixed assets are a proxy of financial condition and the availability of loans with traditional or nontraditional institutions. The coefficient of tangible fixed assets is thus negative for additional equity capital if equity capital and bank loans are substitutes. Tangible fixed assets are defined as tangible fixed assets at the beginning of fiscal year $\mathrm{t}$, normalized by total assets at the beginning of fiscal year $\mathrm{t}$.

As a proxy for productivity, we employ simple revenue-based total factor productivity (TFP). ${ }^{17} \mathrm{We}$ assume a Cobb-Douglas production function and estimate the following equation, dividing the sample by 15 industries and 17 years:

$\ln \left(Y_{i, j, t}\right)=\alpha_{j, t}+\beta_{j, t}^{k} \ln \left(K_{i, j, t}\right)+\beta_{j, t}^{l} \ln \left(L_{i, j, t}\right)+\omega_{i, j, t}$

where $\mathrm{Y}$ is 1 plus a firm's revenue at fiscal year $\mathrm{t}, \mathrm{K}$ is 1 plus a firm's tangible fixed assets at the beginning of fiscal year $\mathrm{t}, \mathrm{L}$ is 1 plus a firm's number of employees at fiscal year $\mathrm{t}$, and $\omega_{i, j, t}$ is the error term of firm $i$ of industry $j$ at year t. ${ }^{18}$ We estimate (2) for all 15 industries and 17 years to control for industry and year heterogeneity, which means 255 industry/year estimations of Eq. 2. We define TFP as the residual for firm

\footnotetext{
${ }^{17}$ Because of a lack of panel data, it is difficult to control endogeneity caused by an omitted variable (such as a productivity shock).

${ }^{18} \mathrm{We}$ add 1 to all variables because some firms' tangible fixed assets and/or number of employees is zero. We remove observations whose revenue is zero, but we also add 1 to revenue to maintain consistency with the definitions of the other variables.
} 


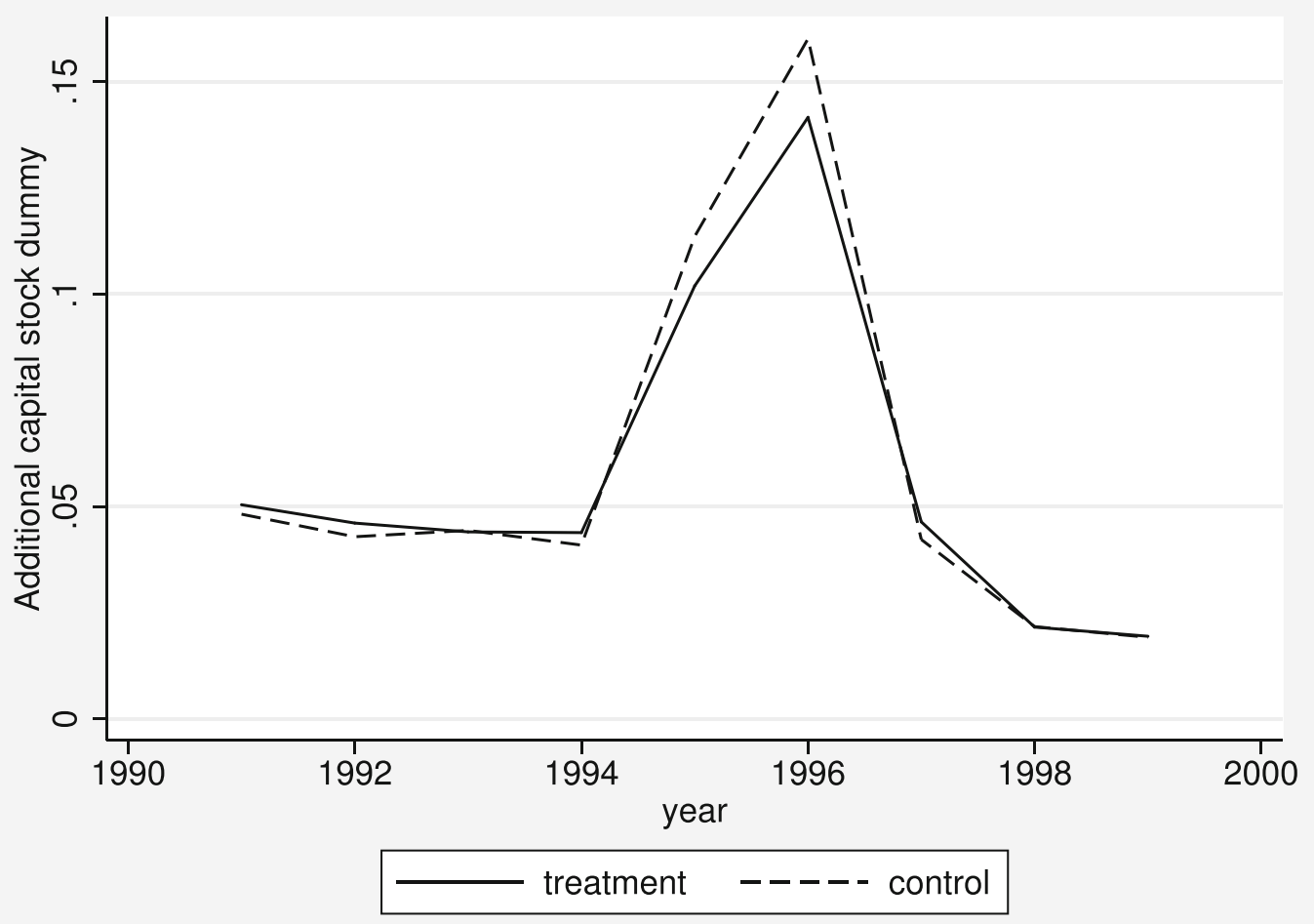

Fig. 1 Pre-trend of Additional Capital Stock Dummy for Treatment1 and Controls. Note: This figure shows the mean of additional capital stock dummy before the policy year

$\mathrm{i}$ in industry $\mathrm{j}$ of year $\mathrm{t}\left(\hat{\omega}_{i, j, t}\right)$ calculated using $\hat{\alpha}_{j, t}$, $\hat{\beta}_{j, t}^{l}$, and $\hat{\beta}_{j, t}^{k}$. We expect that the coefficient of TFP can be either positive or negative. Firms with high productivity can issue more equity. If this is supported, the sign of TFP is positive. On the other hand, firms with low productivity cannot acquire enough credit from banks, so they issue equity to finance investment opportunities. If this is supported, the sign is negative.

\subsection{Effects of changes in requirements in the SME} basic act

\subsubsection{Hypothesis}

In Japan, SMEs can access the various SME policies listed in Table 1. If the opportunity cost of accessing these policies is significant, we predict that firms ensure that they remain within the SME requirements under the SME Basic Act so that they can utilize these SME policies, which is a disincentive for firm growth. If a firm's capital stock is close to the cap specified in the SME Basic Act, they do not have an incentive to increase their capital stock. As a result, firms do not increase their equity capital.

To investigate this research question, we focus on the effects of the change in 1999 in the definition of SMEs in the SME Basic Act. As noted above, this change resulted in the capital stock cap requirement being relaxed from 100 million to 300 million yen for all industries, with the exception of the wholesale, retail, and service industries. Following the 1999 revision, firms with capital stock of around 100 million were able to increase their equity capital but retain their SME status under the requirements of the new Act. If the cap acts as an effective constraint on increases in capital stock, then firms would increase their capital stock after the change in the SME Basic Act. These effects would be magnified if a firm's capital stock was close to the pre-1999 cap. As the cap of 100 million yen does not apply to the wholesale, retail, and service industries, we can regard the firms in these industries as a control group. We employ the difference-in-differences approach and examine whether treatment group firms increased 


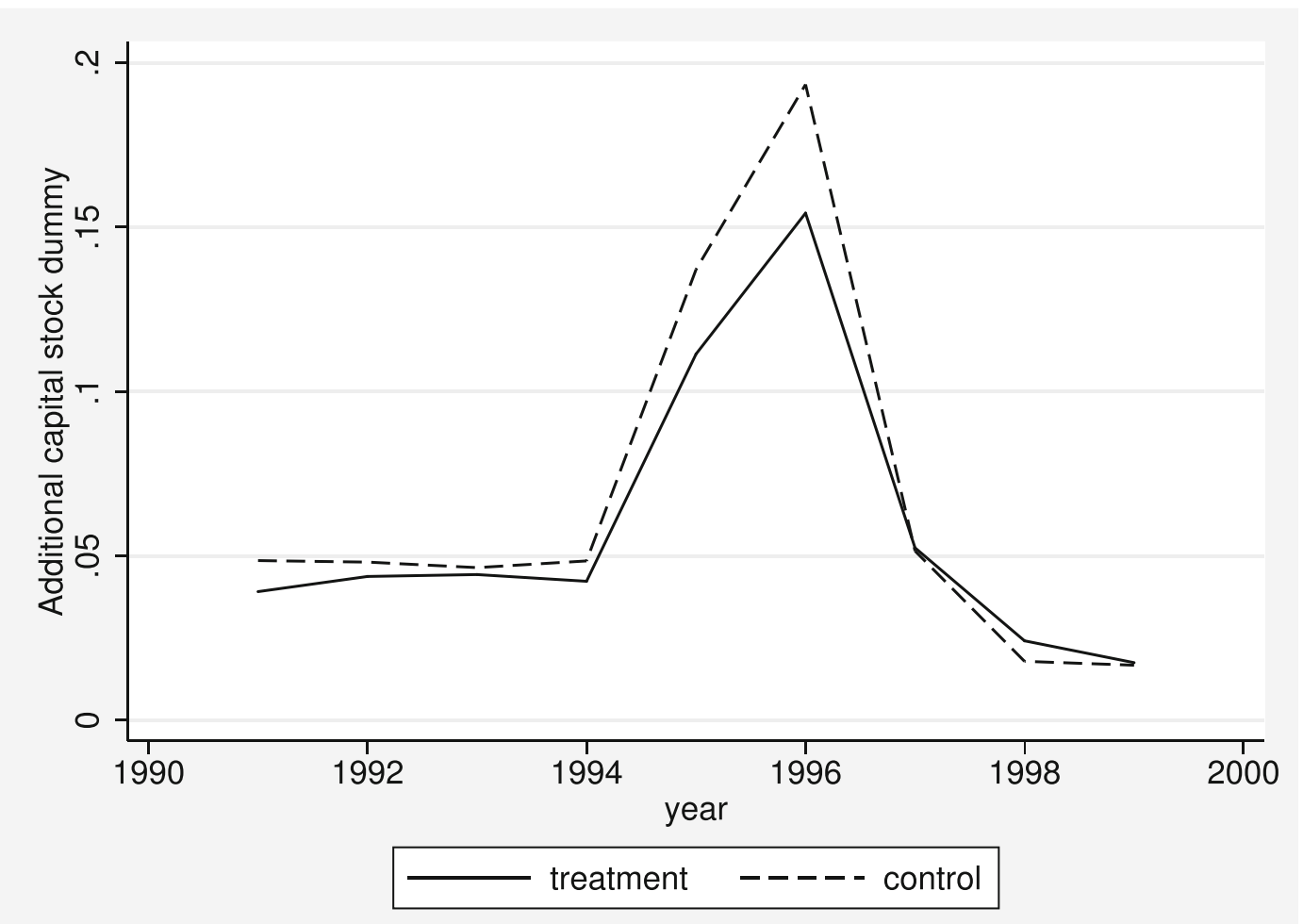

Fig. 2 Pre-trend of Additional Capital Stock Dummy in Treatment2 and Controls. Note: This figure shows the mean of additional capital stock dummy before the policy year

their capital stock after the revision of the SME Basic Act.

Similarly, we test our hypothesis using the wholesale, retail, and service industries as a treatment group and other industries as a control group. As noted above, the capital stock cap rose from 30 million to 100 million for the wholesale industry with the changes to the SME Basic Act. If the cap is an effective constraint, firms with a capital stock of close to 30 million yen in the wholesale industry would not have increased their capital stock before the revision of the SME Basic Act. Furthermore, this effect is significant for the treatment group, that is, firms in the wholesale industry. The effect of the gap between a firm's capital stock and the cap of 30 million yen before the revision is weaker after the revision of the SME Basic Act in the treatment group. Finally, we investigate the case of the retail and service industries. In this case, the cap was 10 million yen before the revision of the SME Basic Act, and so we focus on the gap between a firm's capital stock and the cap of 10 million yen.

\subsubsection{Equation}

To test our hypothesis, we estimate the following equation:

$$
\begin{aligned}
\Delta \text { Capital Stock }_{i, t}= & \beta_{1} \text { Treatment }_{i} \times \text { Policy }_{t} \\
& +\beta_{2} \text { Treatment }_{i} \\
& \times \text { Capital Stock Gap }_{i, t} \\
& +\beta_{3} \text { Treatment }_{i} \\
& \times \text { Capital Stock Gap }_{i, t} \\
& \times \text { Policy }_{t} \\
& +\beta_{4} \text { Capital Stock Gap }_{i, t} \\
& +\mathbf{X}_{i, t} \beta_{\mathbf{5}}+\iota_{t}+\kappa_{i}+\lambda_{i, t}
\end{aligned}
$$

where $\lambda_{i, t}$ is the error term of firm i in fiscal year t, $\kappa_{i}$ is industry fixed effects of 45 industries, and $\iota_{i}$ is year fixed effects from FY1991 to FY2007. The definition of $\Delta$ Capital Stock $_{i, t}$ is the same as in Eq. 1. $\mathbf{X}$ includes leverage at the beginning of fiscal year $t$, tangible fixed assets at the beginning of fiscal year $t$, 


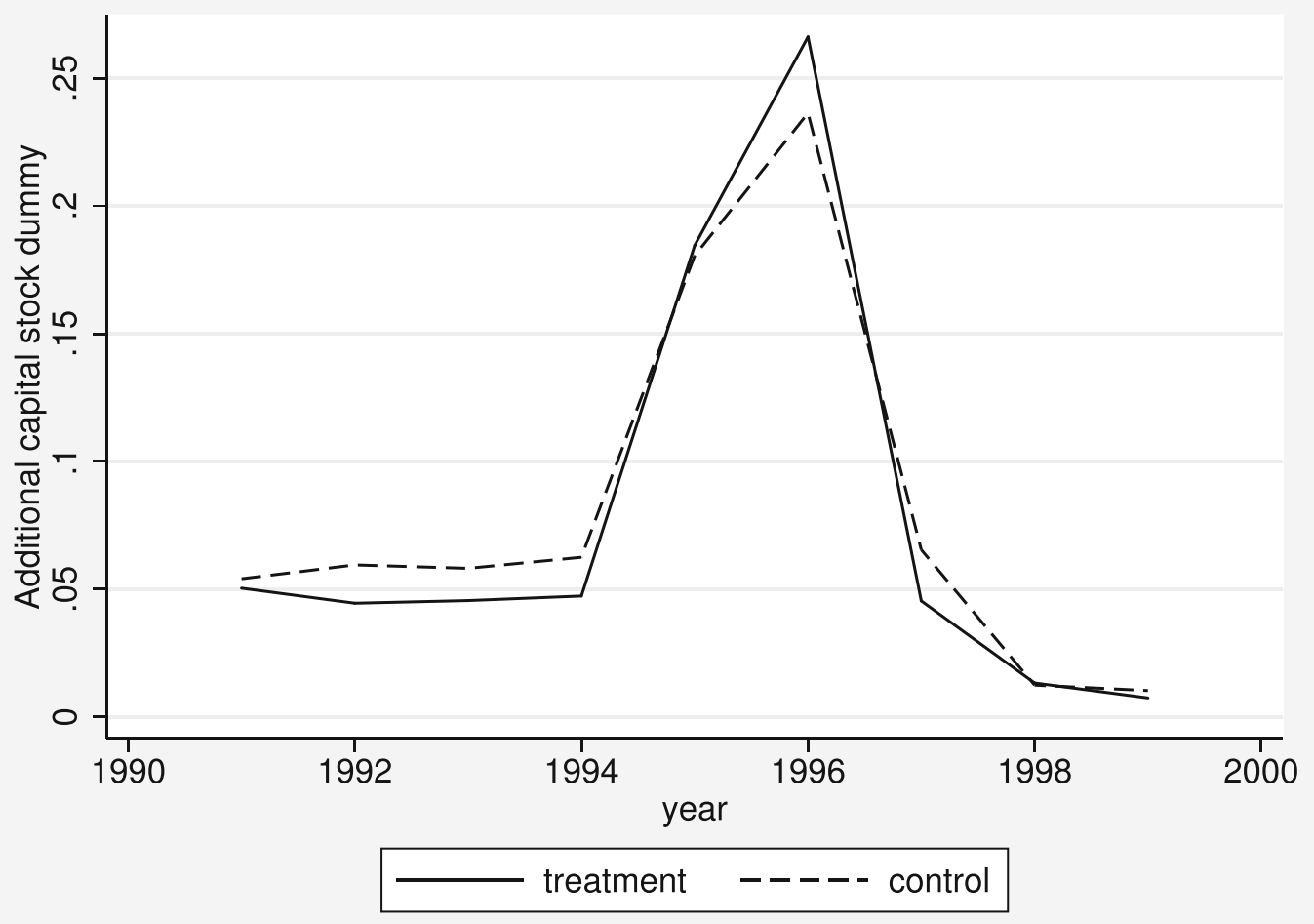

Fig. 3 Pre-trend of Additional Capital Stock Dummy for in Treatment 3 and Controls. Note: This figure shows the mean of additional capital stock dummy before the policy year

operating incomes in fiscal year $t$, and firm size at the beginning of fiscal year t. Firm size is controlled by the natural logarithm of total assets at the beginning of fiscal year t. Larger firms are less risky and can use more capital. Therefore, we predict that the coefficient of firm size is positive.

We use three types of treatment dummy. The first treatment dummy has a value of one if firms do not belong to the wholesale, retail, or service industries, and a value of zero otherwise. This dummy focuses on the change in definition 1, shown in Table 2 (hereafter, Treatment1). The second treatment dummy has a value of one if firms belong to the wholesale industry, and a value of zero otherwise. This dummy focuses on the change in definition 2, shown in Table 2 (hereafter, Treatment2). The third treatment dummy has a value of one if firms belong to the retail and service industries, and a value of zero otherwise. This dummy focuses on the changes in definitions 3 and 4, shown in Table 2 (hereafter, Treatment3).
In addition, we add variables indicating the capital stock gap (Capital Stock Gap in Eq. 3), which is defined as the natural logarithm of the cap on capital stock in the SME Basic Act before 1999 minus a firm's capital stock at the beginning of fiscal year t. We define three types of capital stock gap, depending on the cap on capital stock. Capital Stock Gap1 is defined as the natural logarithm of 100 million yen minus a firm's capital stock at the beginning of fiscal year t. Capital Stock Gap2 is defined as the natural logarithm of 30 million yen minus a firm's capital stock at the beginning of fiscal year t. Capital Stock Gap3 is defined as the natural logarithm of 10 million yen minus a firm's capital stock at the beginning of fiscal year $t$. If firms do not increase their capital stock so that they can continue to satisfy the SME requirements, the treated firms with a smaller capital stock gap increase their lower capital stock.

If treated firms increase their capital stock after the change in the definitions of SMEs in 1999, the 
Table 4 Summary statistics

\begin{tabular}{|c|c|c|c|c|c|c|c|c|}
\hline Variable & $\mathrm{N}$ & mean & sd & $\min$ & $\mathrm{p} 1$ & $\mathrm{p} 50$ & p99 & $\max$ \\
\hline Additional Capital Stock Dummy & 304,342 & 0.046 & 0.209 & 0.000 & 0.000 & 0.000 & 1.000 & 1.000 \\
\hline Amount of Additional Capital Stock & 304,342 & 4.076 & 45.750 & 0.000 & 0.000 & 0.000 & 100.000 & 1500.000 \\
\hline Treatment $1 \times$ Capital Stock Gap1 & 210,439 & 2.599 & 2.129 & 0.000 & 0.000 & 3.932 & 4.615 & 4.615 \\
\hline Capital Stock Gap1 & 210,439 & 4.027 & 1.168 & 0.000 & 0.000 & 4.511 & 4.615 & 4.615 \\
\hline Treatment1 & 210,439 & 0.645 & 0.478 & 0.000 & 0.000 & 1.000 & 1.000 & 1.000 \\
\hline Treatment $2 \times$ Capital Stock Gap 2 & 151,972 & 0.262 & 0.855 & 0.000 & 0.000 & 0.000 & 3.434 & 3.434 \\
\hline Capital Stock Gap2 & 151,972 & 2.857 & 0.897 & 0.000 & 0.000 & 3.045 & 3.434 & 3.434 \\
\hline Treatment 2 & 151,972 & 0.097 & 0.296 & 0.000 & 0.000 & 0.000 & 1.000 & 1.000 \\
\hline Treatment $3 \times$ Capital Stock Gap3 & 106,634 & 0.529 & 0.991 & 0.000 & 0.000 & 0.000 & 2.398 & 2.398 \\
\hline Capital Stock Gap3 & 106,634 & 1.578 & 1.128 & 0.000 & 0.000 & 2.397 & 2.398 & 2.398 \\
\hline Treatment 3 & 106,634 & 0.308 & 0.462 & 0.000 & 0.000 & 0.000 & 1.000 & 1.000 \\
\hline Cash Holdings & 304,342 & 0.179 & 0.183 & 0.000 & 0.000 & 0.122 & 0.867 & 1.000 \\
\hline Leverage & 304,342 & 0.787 & 0.405 & 0.000 & 0.005 & 0.797 & 2.353 & 3.362 \\
\hline Tangible Fixed Assets & 304,342 & 0.340 & 0.270 & 0.000 & 0.000 & 0.287 & 0.966 & 2.200 \\
\hline Operating Income & 304,342 & 0.007 & 0.110 & -0.710 & -0.446 & 0.019 & 0.250 & 0.334 \\
\hline Firm Size & 304,342 & 4.474 & 4.626 & -13.816 & -5.749 & 6.009 & 10.491 & 14.007 \\
\hline TFP & 304,342 & 0.030 & 1.199 & -6.342 & -1.855 & -0.104 & 3.683 & 10.495 \\
\hline Total Asset Growth & 301,456 & 0.025 & 0.221 & -0.993 & -0.449 & -0.003 & 0.931 & 1.707 \\
\hline
\end{tabular}

Note: This table shows the summary statistics of the variables used in the econometric analysis

coefficient of Treatment Tr $_{i} \times$ Policy $_{t}$ is positive. Because treated firms with capital stock close to the cap under the definition of SMEs have less incentive to increase their capital stock, we predict that the coefficient of Treatment Tr $_{i} \times$ Capital Stock Gap $_{i, t}$ is negative. In addition, if the incentive to increase capital stock is weakened by the cap set in the definition of SMEs, firms will increase their capital stock after the revision of the Act relaxed the cap. Therefore, because the effects of Treatment $t_{i} \times$ Capital Stock Gapi,t are smaller after the change in the definition of SMEs, we predict that the coefficient of Treatment $_{i} \times$ Capital Stock Gap C $_{i, t} \times$ Policy $_{t}$ is negative. The coefficient of Capital Stock Gapi,t controls the effects of Capital Stock Gap ${ }_{i, t}$ on $\triangle$ Capital Stock ${ }_{i, t}$ for both the treated and control groups. We control the effects of Treatment $t_{i}$ by industry fixed effects and those of Policy $y_{t}$ by year fixed effects.

In Figs. 1, 2, and 3, we show the pre-trend of the additional capital stock dummy, divided by treatment and control groups. These figures indicate that the trends in the additional capital stock are similar among treatment and control groups, suggesting that firms in a different sector are a valid counterfactual.

\subsection{Consequences of changes in capital stock}

\subsubsection{Hypothesis}

As a consequence of increasing capital stock and acquiring additional equity capital, firms can increase their inventory and/or capital investment, which induces asset growth of firms. As these actions enhance firm value, we predict that the change in the SME capital stock requirements will lead to firm growth. ${ }^{19}$ If this prediction is supported, low levels of capital stock, caused by the cap in the definition of SMEs, impede firm growth by decreasing acquisitions of equity capital. However, firms can use other financial sources to finance investment opportunities, such

\footnotetext{
${ }^{19}$ The consequence of additional equity capital is not only firm growth. Ou and Haynes (2006) argue that firms avoid defaulting on loans as additional equity capital mitigates liquidity shortages.
} 
as bank loans. In this case, the effects of additional capital stock on firm growth are not significant.

In addition, we investigate the effects of equity issues on debt finance. If capital stock constraints are severe for small businesses, they will use other financial sources, including bank loans. As a result, we assume that, prior to the changes in the SME Basic Act, firms would have used debt rather than equity beyond the level that was optimal. If this is accurate, the coefficient of additional equity on total debt growth will be negative. On the other hand, if the relationship between equity issues and debt finance is complementary, the coefficient of additional equity will be positive. The reason for this positive relationship is that firms with equity issues would become more creditworthy, and the supply of bank loans would increase.

\subsubsection{Equation}

To investigate the consequence of additional equity capital, we estimate the following regression:

$$
\begin{aligned}
\text { Growt }_{i, t}= & \gamma_{1} \Delta \text { Capital Stock }_{i, t} \\
& +\mathbf{Y}_{i, t} \gamma_{2}+\mu_{t}+v_{i}+\xi_{i, t} \\
\Delta \text { Capital Stock }_{i, t}^{*}= & \mathbf{Z}_{i, t} \omega_{1}+\mathbf{X}_{i, t} \omega_{2}+\emptyset_{t} \\
& +\pi_{i}+\tau_{i, t} \\
& \Delta \text { Capital Stock }{ }_{i, t} \\
= & 1 \text { if } \Delta \text { Capital Stock } k_{i, t}^{*}>0 \\
& \Delta \text { Capital Stock } k_{i, t} \\
= & 0 \text { otherwise }
\end{aligned}
$$

where $x i_{i, t} \sim N\left(0, \sigma^{2}\right), \tau_{i, t} \sim N\left(0, \sigma^{2}\right)$, and $\operatorname{Cov}\left(\xi_{i, t}, \tau_{i, t}\right)=\rho \neq 0 . v_{i}$ and $\pi_{i}$ are industry fixed effects of 48 industries and $\mu_{t}$ and $\emptyset_{t}$ are year fixed effects from FY1991 to FY2007.

We use several proxies as the dependent variable: asset growth, debt growth, tangible fixed asset growth, and inventory growth. Asset growth is defined as the annual change in total assets from the beginning to the end of fiscal year $t$, which is normalized by total assets at the beginning of fiscal year t. Debt growth is defined as the annual change in total debts from the beginning to the end of fiscal year $t$, which is normalized by total assets at the beginning of fiscal year t. Tangible fixed asset growth is defined as the annual change in tangible fixed assets from the beginning to the end of fiscal year $\mathrm{t}$, which is normalized by total assets at the beginning of fiscal year t. Inventory growth is defined as the annual change in inventories from the beginning to the end of fiscal year $t$, which is normalized by total assets at the beginning of fiscal year $t$. We use the additional capital stock dummy as a proxy of $\Delta$ Capital Stock ${ }_{i, t} . \mathbf{Y}_{i, t}$ includes cash holdings at the beginning of fiscal year $t$, leverage at the beginning of fiscal year $\mathrm{t}$, tangible fixed assets at the beginning of fiscal year $t$, operating income in fiscal year $t$, TFP in fiscal year $\mathrm{t}$, and firm size at the beginning of fiscal year t. As we argued above, $\Delta$ Capital Stock $_{i, t}$ is determined by many variables, which include the level of a firm's capital stock and the change in the definition of SMEs. Therefore, because $\Delta$ Capital Stock ${ }_{i, t}$ is a nonrandom variable, we should control for possible endogeneity. We use a treatment effects model to mitigate any endogeneity bias. We estimate the parameter vectors using a maximum-likelihood method. In Eq. 5, we employ variables $\left(\mathbf{X}_{i, t}\right)$ in Eqs. 1 and 3. In addition, we employ several types of $\mathbf{Z}_{i, t}$ : Capital Stock Dummy $y_{i, t}^{j}$ in Eq. 1, and Treatment ${ }_{i} \times$ Policy $_{t}$, Treatment $_{i} \times$ Capital Stock Gap ${ }_{i, t}$, Treatment $_{i} \times$ Capital Stock Gap T $_{i, t} \times$ Policy $_{t}$, and Capital Stock Gap ${ }_{i, t}$ in Eq. 3.

\section{Estimation results}

\subsection{Cap on capital stock}

Table 4 shows summary statistics for each of the variables. As we omit outliers, the minimum and maximum of each variable are not extreme values. Table 3 shows the mean values of each dummy. Table 5 shows the estimation results for Eq. 1 using the additional capital stock dummy and the amount of $\Delta$ capital stock. As the additional capital stock dummy is a binary variable, we employ a maximum-likelihood probit model. Furthermore, as Table 4 shows, the amount of $\Delta$ capital stock has a lower limit of zero. Therefore, we employ a tobit model. In column (1), we show the estimation results using the additional capital stock dummy. The benchmark is observations with 10 million yen or less of capital stock, so that each estimated coefficient shows the magnitude of additional capital stock compared with firms with 10 million yen or less of capital stock. The estimated coefficient for the capital stock dummy from 20M to $60 \mathrm{M}$ is negative and statistically significant at the $1 \%$ 


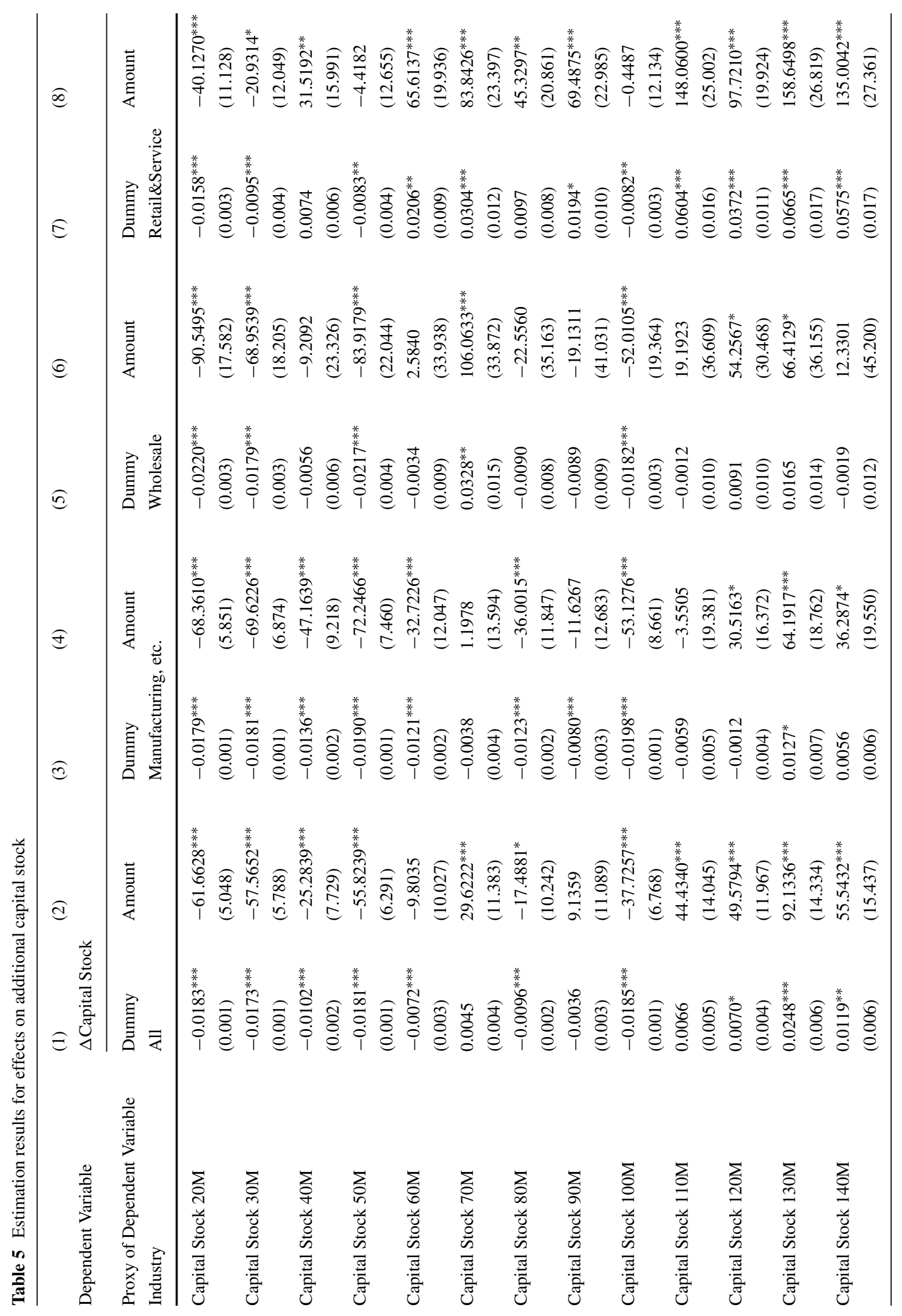




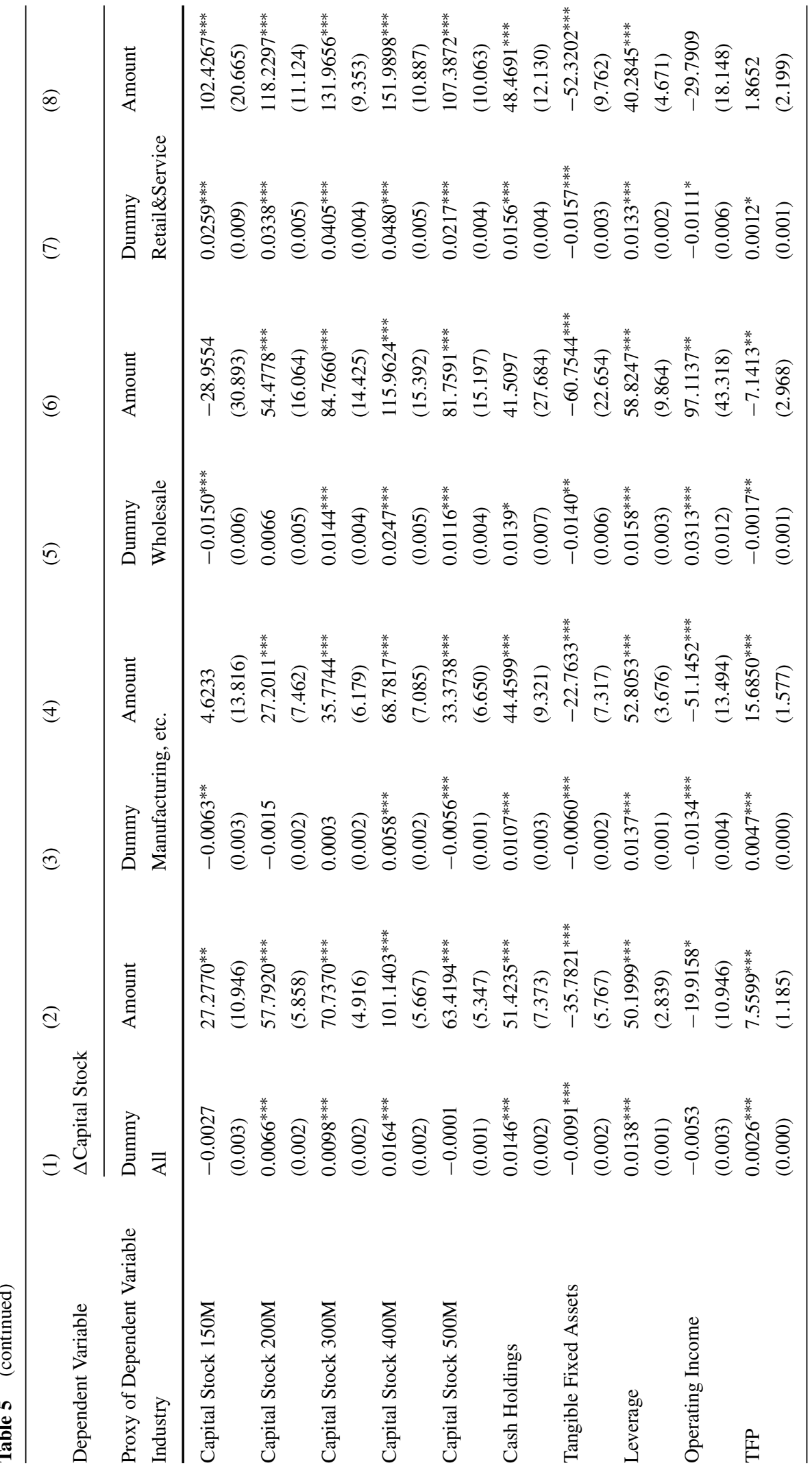




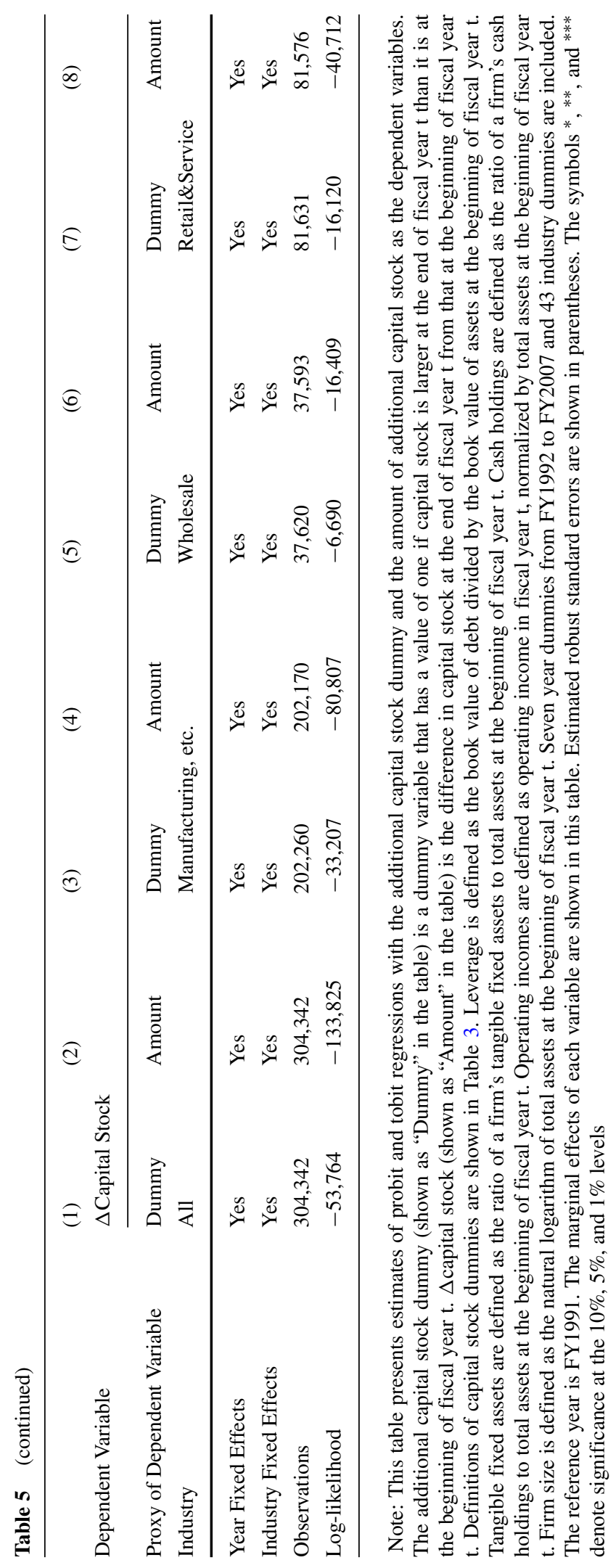




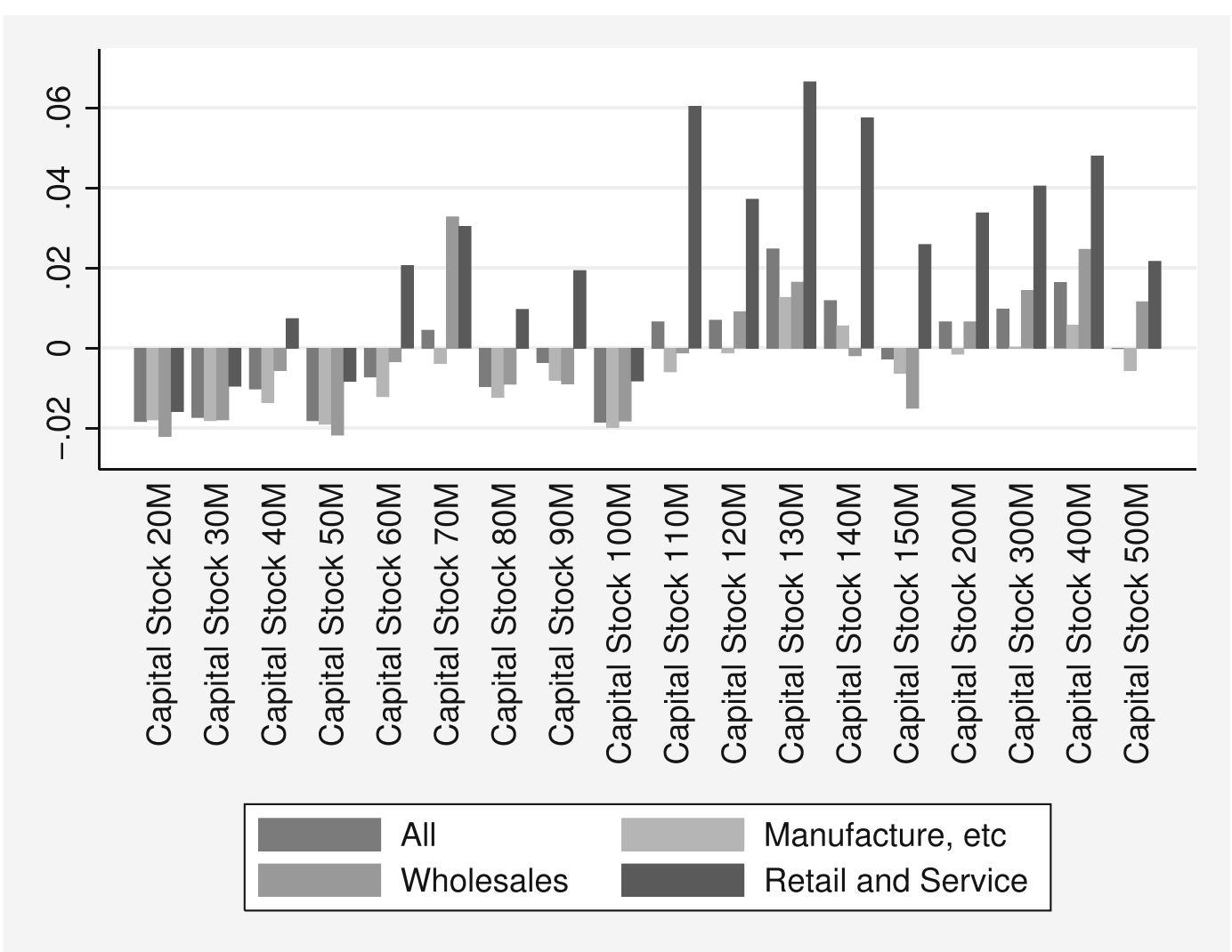

Fig. 4 Magnitude of Estimated Marginal Effects of Capital Stock Dummies on Additional Capital Stock Dummy, by Industry. Note: This figure shows the estimated marginal effects of capital stock dummies on additional capital stock dummy using the probit estimation. The estimated result for all firms is shown in column (1) of Table 5. Other results are not reported in any table level, suggesting that firms with 60 million yen or less of capital stock are less likely to increase their capital stock. The estimated coefficients of the capital stock dummy for $80 \mathrm{M}$ and $100 \mathrm{M}$ are also negative and statistically significant at the $1 \%$ level. Focusing on magnitude, the estimated negative coefficient of the capital stock $100 \mathrm{M}$ is the highest, although the many estimated coefficients for over $100 \mathrm{M}$ are positive and statistically significant. Column (2) shows the estimation results of the tobit regression using the amount of $\Delta$ capital stock as the dependent variable. The signs of the estimation results are almost the same as those in column (1). In terms of magnitude, although the estimated negative coefficient of capital stock $100 \mathrm{M}$ is not the highest, it remains high compared with similar level capital stock dummies.

Columns (3)-(8) show the estimation results, divided by three groups of industries. Columns (3) and (4) show the estimation results for manufacturing, etc., columns (5) and (6) show those for wholesale, and columns (7) and (8) show those for retail and service. The estimation results of capital stock 100M are similar between manufacturing, etc. and wholesale. If the cap of capital stock requirement of the old SME Basic Act for the wholesale industry has significant effects, the coefficient of capital stock $30 \mathrm{M}$ is negative for only the wholesale industry. However, the magnitudes of the estimated coefficients of capital stock $30 \mathrm{M}$ for wholesale are similar to those for manufacturing. Focusing on retail and service, we see that the estimated coefficient for capital stock $100 \mathrm{M}$ is negative and statistically significant in column (7), but not significant in column (8). However, the estimated coefficients of capital stock $110 \mathrm{M}$ or over and those between $60 \mathrm{M}$ and $90 \mathrm{M}$ are positive and statistically significant at the $1 \%$ level. Similar to the results in 


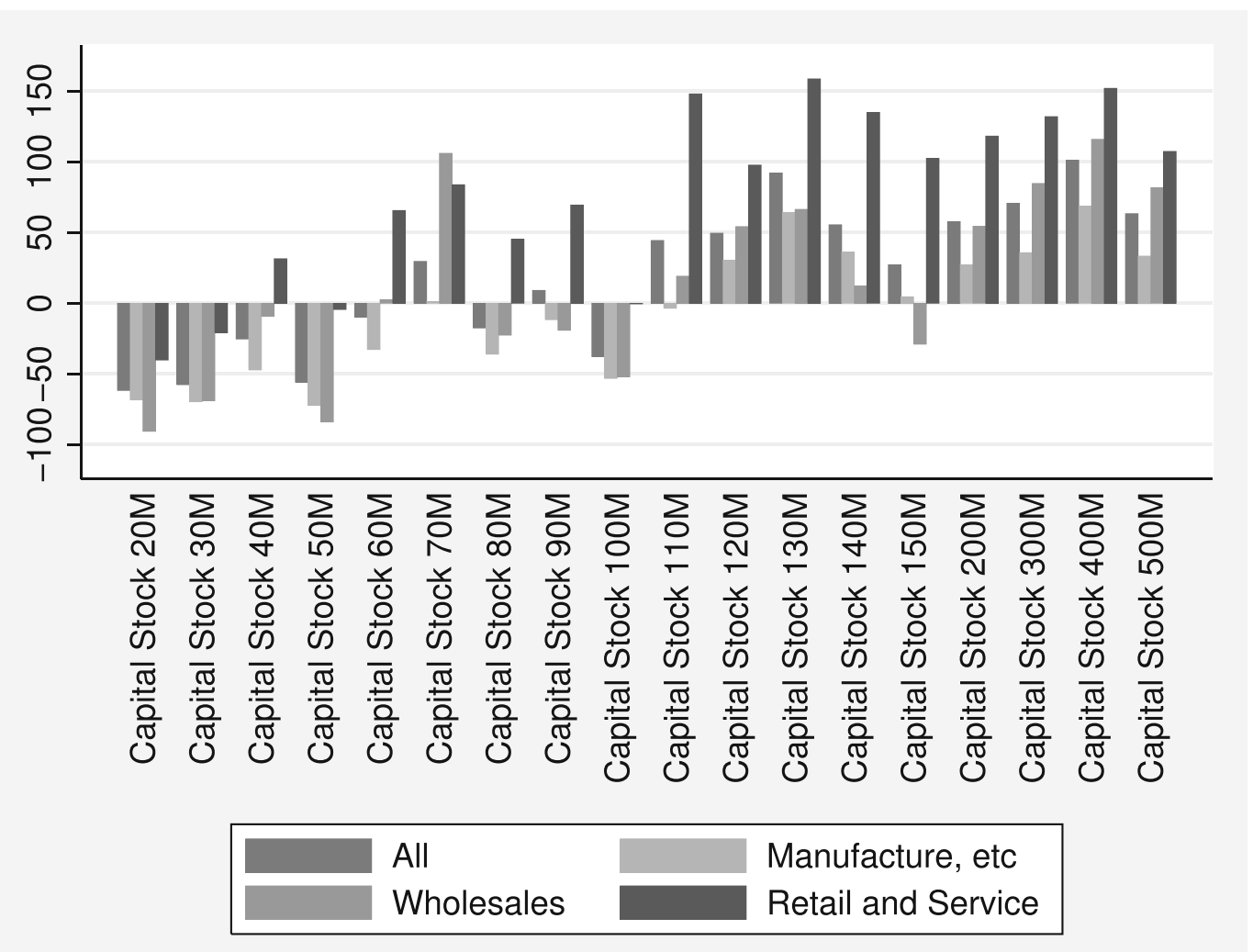

Fig. 5 Magnitude of Estimated Coefficients of Capital Stock Dummies on Additional Capital Stock, by Industry. Note: This figure shows the estimated coefficient of capital stock dummies

other columns, the magnitude of the estimated coefficient of capital stock 100M is also smaller, compared with the similar size of capital stock (column 8).

To compare the estimated coefficients of the capital stock dummies, Fig. 4 (using the additional capital stock dummy as the dependent variable) and Fig. 5 (using the amount of $\Delta$ capital stock as the dependent variable) show bar graphs of the estimated coefficients of the capital stock dummies. We show the estimated coefficients of the capital stock dummies using all firms in Table 5 . In addition, we show the estimated coefficients of the capital stock dummies for the three separate categories of industries in Figs. 4 and 5. Figures 4 and 5 show that the impacts of almost all capital stock dummies are negative for the $50 \mathrm{M}$ or less capital stock dummies. This implies that firms with 10 million yen or less of capital stock are very small firms. As Berger and Udell (1998) argue, they rely on insider equity because external finance is less available than it is for larger on additional capital stock using the tobit estimation. The estimated result for all firms is shown in column (2) of Table 5. Other results are not reported in any table

firms, because of information asymmetry. On the other hand, firms with between 10 and 50 million yen of capital stock can use external finance, so their estimated coefficients are negative compared with firms with 10 million or less of capital stock. Focusing on the over 60M capital stock dummies, we see that the estimated coefficients are positive or nearly zero, but then, for the $100 \mathrm{M}$ capital stock dummies, they are negative. In the area of the graph showing the over $100 \mathrm{M}$ capital stock dummies, almost all the estimated coefficients are positive because these firms are creditworthy and can use external equity. Moreover, the graph suggests that there is a large gap between firms with 100 million yen of capital stock and those with over 100 million yen of capital stock.

In sum, these results imply that firms with 100 million yen of capital stock or less increase capital stock less than larger firms, whereas these effects are small in firms with over 100 million yen of capital stock. As 
Table 6 Estimation results for the effects of changing the definitions of SMEs on the manufacturing industry

\begin{tabular}{|c|c|c|c|c|}
\hline \multirow{3}{*}{$\begin{array}{l}\text { Dependent Variable } \\
\text { Proxy of Dependent Variable }\end{array}$} & (1) & (2) & (3) & (4) \\
\hline & \multicolumn{4}{|c|}{$\Delta$ Capital Stock } \\
\hline & Dummy & Amount & Dummy & Amount \\
\hline Period of Policy & FY2000 & FY2000 & FY1999 & FY1999 \\
\hline \multirow[t]{2}{*}{ Treatment $1 \times$ Policy } & $0.0591^{* * *}$ & $42.7181^{* * *}$ & $0.0630^{* * *}$ & $45.6963^{* * *}$ \\
\hline & $(0.008)$ & $(9.571)$ & $(0.008)$ & $(9.540)$ \\
\hline \multirow[t]{2}{*}{ Treatment $1 \times$ Capital Stock Gap1 } & $0.0080^{* * *}$ & $7.7454^{* * *}$ & $0.0088^{* * *}$ & $8.4484^{* * *}$ \\
\hline & $(0.001)$ & $(1.821)$ & $(0.001)$ & $(1.892)$ \\
\hline \multirow{2}{*}{$\begin{array}{l}\text { Treatment } 1 \times \text { Capital Stock Gap1 } \\
\times \text { Policy }\end{array}$} & $-0.0115^{* * *}$ & $-11.9014^{* * *}$ & $-0.0123^{* * *}$ & $-12.4847^{* * *}$ \\
\hline & $(0.001)$ & $(2.170)$ & $(0.001)$ & $(2.169)$ \\
\hline \multirow[t]{2}{*}{ Capital Stock Gap1 } & $0.0035^{* * *}$ & 0.0984 & $0.0036^{* * *}$ & 0.1051 \\
\hline & $(0.001)$ & $(1.036)$ & $(0.001)$ & $(1.037)$ \\
\hline \multirow[t]{2}{*}{ Cash Holdings } & $0.0100^{* * *}$ & $13.9210^{* * *}$ & $0.0100^{* * *}$ & $13.9363^{* * *}$ \\
\hline & $(0.002)$ & $(3.840)$ & $(0.002)$ & $(3.842)$ \\
\hline \multirow[t]{2}{*}{ Tangible Fixed Assets } & $-0.0087^{* * *}$ & $-14.4751^{* * *}$ & $-0.0087^{* * *}$ & $-14.4931^{* * *}$ \\
\hline & $(0.002)$ & $(3.035)$ & $(0.002)$ & $(3.036)$ \\
\hline \multirow[t]{2}{*}{ Leverage } & $0.0151^{* * *}$ & $23.8876^{* * *}$ & $0.0151^{* * *}$ & $23.9036^{* * *}$ \\
\hline & $(0.001)$ & $(1.711)$ & $(0.001)$ & $(1.711)$ \\
\hline \multirow[t]{2}{*}{ Operating Income } & -0.0040 & $-12.9832^{* * *}$ & -0.0041 & $-13.0891^{* * *}$ \\
\hline & $(0.003)$ & $(4.866)$ & $(0.003)$ & $(4.869)$ \\
\hline \multirow[t]{2}{*}{ TFP } & $0.0015^{* * *}$ & $2.2751^{* * *}$ & $0.0015^{* * *}$ & $2.2664^{* * *}$ \\
\hline & $(0.000)$ & $(0.833)$ & $(0.000)$ & $(0.833)$ \\
\hline \multirow[t]{2}{*}{ Firm Size } & $0.0009^{* * *}$ & $2.0544^{* * *}$ & $0.0009^{* * *}$ & $2.0604^{* * *}$ \\
\hline & $(0.000)$ & $(0.217)$ & $(0.000)$ & $(0.217)$ \\
\hline Year Fixed Effects & Yes & Yes & Yes & Yes \\
\hline Industry Fixed Effects & Yes & Yes & Yes & Yes \\
\hline Observations & 210,439 & 210,439 & 210,439 & 210,439 \\
\hline Log-likelihood & -33470 & -75229 & -33460 & -75224 \\
\hline
\end{tabular}

Note: This table presents estimates of probit and tobit regressions with the additional capital stock dummy and the amount of additional capital stock as the dependent variables. The additional capital stock dummy (shown as "Dummy" in the table) is a dummy variable that has a value of one if capital stock is larger at the end of fiscal year $t$ than at the beginning of fiscal year $t$. Additional capital stock (shown as "Amount" in the table) is the difference in capital stock at the end of fiscal year t from that at the beginning of fiscal year t. Treatment 1 has a value of one if firms do not belong to the wholesale, retail, or service industries, and a value of zero otherwise, in order to focus on the change in Definition 1, shown in Table 2. Policy has a value of one if the year is after FY2000 in columns (1) and (2), and after FY1999 in columns (3) and (4). Capital Stock Gap1 is defined as the natural logarithm of 100 million yen minus a firm's capital stock at the beginning of fiscal year t. Definitions of other independent variables are shown in the note to Table 5. The marginal effects of each variable are shown in this table. Estimated robust standard errors are shown in parentheses. The symbols *, **, and ${ }^{* * *}$ denote significance at the $10 \%, 5 \%$, and $1 \%$ levels

the cap in capital stock for SMEs is set at 100 million yen in the Corporation Tax Act and SME Basic Act (for manufacturing and other industries before 1999), these negative effects on additional capital stock are caused by the incentive to retain SME status. Table 5 shows that the estimated coefficients of cash holdings, leverage, and TFP (apart from column 6) are positive, whereas those of tangible fixed assets and operating income are negative. All estimated coefficients are statistically significant at the $1 \%$ level. These results suggest that highly leveraged firms increase equity capital to mitigate the cost of high leverage. The negative coefficients for tangible fixed assets suggest that firms with high collateral assets can increase bank 
Table 7 Estimation results for the effects of changing the definitions of SMEs on the wholesale industry

\begin{tabular}{|c|c|c|c|c|}
\hline \multirow{4}{*}{$\begin{array}{l}\text { Dependent Variable } \\
\text { Proxy of Dependent Variable } \\
\text { Period of Policy }\end{array}$} & (1) & (2) & (3) & (4) \\
\hline & \multicolumn{4}{|c|}{$\Delta$ Capital Stock } \\
\hline & Dummy & Amount & Dummy & Amount \\
\hline & FY2000 & FY2000 & FY1999 & FY1999 \\
\hline \multirow[t]{2}{*}{ Treatment $2 \times$ Policy } & $0.1368^{* * *}$ & $42.6807^{* * *}$ & $0.1586^{* * *}$ & $47.3646^{* * *}$ \\
\hline & $(0.050)$ & $(12.348)$ & $(0.054)$ & (12.495) \\
\hline \multirow[t]{2}{*}{ Treatment $2 \times$ Capital Stock Gap2 } & $0.0080^{* *}$ & $6.4785^{* *}$ & $0.0095^{* *}$ & $7.3787^{* *}$ \\
\hline & $(0.004)$ & $(2.912)$ & $(0.004)$ & $(3.100)$ \\
\hline \multirow{2}{*}{$\begin{array}{l}\text { Treatment } 2 \times \text { Capital Stock Gap2 } \\
\times \text { Policy }\end{array}$} & $-0.0228^{* * *}$ & $-15.7847^{* * *}$ & $-0.0247^{* * *}$ & $-16.2179^{* * *}$ \\
\hline & $(0.005)$ & $(4.355)$ & $(0.005)$ & $(4.273)$ \\
\hline \multirow[t]{2}{*}{ Capital Stock Gap2 } & $0.0171^{* * *}$ & $11.3493^{* * *}$ & $0.0171^{* * *}$ & $11.3433^{* * *}$ \\
\hline & $(0.001)$ & $(1.522)$ & $(0.001)$ & $(1.517)$ \\
\hline \multirow[t]{2}{*}{ Cash Holdings } & $0.0094^{* * *}$ & $8.3540^{* * *}$ & $0.0093^{* * *}$ & $8.3395^{* * *}$ \\
\hline & $(0.002)$ & $(2.921)$ & $(0.002)$ & $(2.921)$ \\
\hline \multirow[t]{2}{*}{ Tangible Fixed Assets } & $-0.0085^{* * *}$ & $-7.0419^{* * *}$ & $-0.0085^{* * *}$ & $-7.0482^{* * *}$ \\
\hline & $(0.002)$ & $(2.017)$ & $(0.002)$ & $(2.020)$ \\
\hline \multirow[t]{2}{*}{ Leverage } & $0.0131^{* * *}$ & $10.4897^{* * *}$ & $0.0131^{* * *}$ & $10.4914^{* * *}$ \\
\hline & $(0.001)$ & $(1.280)$ & $(0.001)$ & $(1.281)$ \\
\hline \multirow[t]{2}{*}{ Operating Income } & 0.0032 & 0.8207 & 0.0032 & 0.8130 \\
\hline & $(0.003)$ & $(2.605)$ & $(0.003)$ & $(2.606)$ \\
\hline \multirow[t]{2}{*}{ TFP } & $0.0017^{* * *}$ & $1.6539^{* *}$ & $0.0017^{* * *}$ & $1.6560^{* *}$ \\
\hline & $(0.001)$ & $(0.790)$ & $(0.001)$ & $(0.791)$ \\
\hline \multirow[t]{2}{*}{ Firm Size } & $0.0025^{* * *}$ & $2.3598^{* * *}$ & $0.0025^{* * *}$ & $2.3601^{* * *}$ \\
\hline & $(0.000)$ & $(0.272)$ & $(0.000)$ & $(0.271)$ \\
\hline Year Fixed Effects & Yes & Yes & Yes & Yes \\
\hline Industry Fixed Effects & Yes & Yes & Yes & Yes \\
\hline Observations & 151,972 & 151,972 & 151,972 & 151,972 \\
\hline Log-likelihood & $-24,635$ & $-53,166$ & $-24,631$ & $-53,165$ \\
\hline
\end{tabular}

Note: This table presents estimates of probit and tobit regressions with the additional capital stock dummy and the amount of additional capital stock as the dependent variables. The additional capital stock dummy (shown as "Dummy" in the table) is a dummy variable with a value of one if the capital stock is larger at the end of fiscal year $t$ than at the beginning of fiscal year t. Additional capital stock (shown as "Amount" in the table) is the difference in capital stock at the end of fiscal year $t$ from that at the beginning of fiscal year $t$. Treatment 2 has a value of one if firms belong to the wholesale industry and a value of zero otherwise, which enables us to focus on the change in Definition 2, shown in Table 2. Policy has a value of one if the year is after FY2000 in columns (1) and (2), and after FY1999 in columns (3) and (4). Capital Stock Gap2 is defined as the natural logarithm of 30 million yen minus a firm's capital stock at the beginning of fiscal year t. Definitions of other independent variables are shown in the note to Table 5. The marginal effects of each variable are shown in this table. Estimated robust standard errors are shown in parentheses. The symbols *, ${ }^{* *}$, and ${ }^{* * *}$ denote significance at the $10 \%, 5 \%$, and $1 \%$ levels

loans, so they increase their additional equity less than do firms with fewer collateral assets.

\subsection{Changes in requirements under the SME basic act}

In the previous subsection, we show that firms increase capital stock less if a firm's capital stock is 100 million yen or less. We interpret this as indicating that firms increase their capital stock less to remain within the SME requirements and retain their SME status. However, the results could also be interpreted as indicating that it is difficult for firms with 100 million yen or less of capital stock to increase their capital stock because they are SMEs that face serious information asymmetry with investors. Therefore, we conduct another test focusing on an exogenous event, 
Table 8 Estimation results for the effects of changing the definitions of SMEs on the retail and service industries

\begin{tabular}{|c|c|c|c|c|}
\hline \multirow{4}{*}{$\begin{array}{l}\text { Dependent Variable } \\
\text { Proxy of Dependent Variable } \\
\text { Period of Policy }\end{array}$} & (1) & (2) & (3) & (4) \\
\hline & \multicolumn{4}{|c|}{$\Delta$ Capital Stock } \\
\hline & Dummy & Amount & Dummy & Amount \\
\hline & FY2000 & FY2000 & FY1999 & FY1999 \\
\hline \multirow[t]{2}{*}{ Treatment $3 \times$ Policy } & $0.0426^{* * *}$ & $18.1331^{* * *}$ & $0.0428^{* * *}$ & $17.5509^{* * *}$ \\
\hline & $(0.008)$ & $(4.041)$ & $(0.007)$ & $(3.760)$ \\
\hline \multirow[t]{2}{*}{ Treatment $3 \times$ Capital Stock Gap3 } & $0.0047^{* * *}$ & $3.3889^{* * *}$ & $0.0052^{* * *}$ & $3.7398^{* * *}$ \\
\hline & $(0.001)$ & $(1.269)$ & $(0.001)$ & $(1.311)$ \\
\hline \multirow{2}{*}{$\begin{array}{l}\text { Treatment } 3 \times \text { Capital Stock Gap3 } \\
\times \text { Policy }\end{array}$} & $-0.0159^{* * *}$ & $-11.7819^{* * *}$ & $-0.0164^{* * *}$ & $-12.0023^{* * *}$ \\
\hline & $(0.002)$ & $(2.075)$ & $(0.002)$ & $(2.079)$ \\
\hline \multirow[t]{2}{*}{ Capital Stock Gap3 } & $0.0608^{* * *}$ & $37.1325^{* * *}$ & $0.0608^{* * *}$ & $37.1494^{* * *}$ \\
\hline & $(0.001)$ & $(5.896)$ & $(0.001)$ & $(5.900)$ \\
\hline \multirow[t]{2}{*}{ Cash Holdings } & $0.0232^{* * *}$ & $15.3171^{* * *}$ & $0.0232^{* * *}$ & $15.3320^{* * *}$ \\
\hline & $(0.002)$ & $(3.983)$ & $(0.002)$ & $(3.987)$ \\
\hline \multirow[t]{2}{*}{ Tangible Fixed Assets } & $-0.0041^{* *}$ & $-3.6862^{*}$ & $-0.0041^{* *}$ & $-3.6671^{*}$ \\
\hline & $(0.002)$ & $(2.040)$ & $(0.002)$ & $(2.041)$ \\
\hline \multirow[t]{2}{*}{ Leverage } & $0.0113^{* * *}$ & $7.9022^{* * *}$ & $0.0113^{* * *}$ & $7.9071^{* * *}$ \\
\hline & $(0.001)$ & $(1.422)$ & $(0.001)$ & $(1.423)$ \\
\hline \multirow[t]{2}{*}{ Operating Income } & $-0.0147^{* * *}$ & $-8.5804^{* * *}$ & $-0.0147^{* * *}$ & $-8.5828^{* * *}$ \\
\hline & $(0.003)$ & $(2.728)$ & $(0.003)$ & $(2.729)$ \\
\hline \multirow[t]{2}{*}{ TFP } & $0.0098^{* * *}$ & $5.1052^{* * *}$ & $0.0098^{* * *}$ & $5.1050^{* * *}$ \\
\hline & $(0.001)$ & $(1.481)$ & $(0.001)$ & $(1.481)$ \\
\hline \multirow[t]{2}{*}{ Firm Size } & $0.0136^{* * *}$ & $8.9122^{* * *}$ & $0.0136^{* * *}$ & $8.9156^{* * *}$ \\
\hline & $(0.000)$ & $(1.344)$ & $(0.000)$ & $(1.345)$ \\
\hline Year Fixed Effects & Yes & Yes & Yes & Yes \\
\hline Industry Fixed Effects & Yes & Yes & Yes & Yes \\
\hline Observations & 106,634 & 106,634 & 106,634 & 106,634 \\
\hline Log-likelihood & -14366 & -37599 & -14360 & -37596 \\
\hline
\end{tabular}

Note: This table presents estimates of probit and tobit regressions with the additional capital stock dummy and the amount of additional capital stock as the dependent variables. Additional capital stock dummy (shown as "Dummy" in the table) is a dummy variable with a value of one if capital stock is larger at the end of fiscal year $t$ than at the beginning of fiscal year t. The additional capital stock (shown as "Amount" in the table) is the difference in capital stock at the end of fiscal year t from that at the beginning of fiscal year t. Treatment 3 has a value of one if firms belong to the retail and service industries and a value of zero otherwise, which enables us to focus on the change in Definition 3, shown in Table 2. Policy has a value of one if the year is after FY2000 in columns (1) and (2), and after FY1999 in columns (3) and (4). Capital Stock Gap2 is defined as the natural logarithm of 10 million yen minus a firm's capital stock at the beginning of fiscal year t. Definitions of other independent variables are shown in the note to Table 5. The marginal effects of each variable are shown in this table. Estimated robust standard errors are shown in parentheses. The symbols *, ${ }^{* *}$, and ${ }^{* * *}$ denote significance at the $10 \%, 5 \%$, and $1 \%$ levels

which is the change in the definition of SMEs in the SME Basic Act. If SMEs limit their capital stock to remain within the SME requirements, rather than being because of information asymmetry, they will increase their capital stock after the relaxation of these constraints following revision of the SME Basic Act.
Table 6 shows the estimation results for treatment 1 . We limit observations to firms with 100 million or less of capital stock at the beginning of the fiscal year. Columns (1) and (2) show the estimation results for policy, which has a value of one if the year is after FY2000. To check robustness, we also show the 
Table 9 Estimated results of treatment effects regression for additional capital stock on asset growth

\begin{tabular}{|c|c|c|c|c|}
\hline & (1) & (2) & (3) & (4) \\
\hline Additional Capital Stock Dummy & $\begin{array}{l}0.1215^{* * *} \\
(0.003)\end{array}$ & $\begin{array}{l}0.0878^{* * *} \\
(0.004)\end{array}$ & $\begin{array}{l}0.0616^{* * *} \\
(0.005)\end{array}$ & $\begin{array}{l}0.0425^{* * *} \\
(0.006)\end{array}$ \\
\hline Cash Holdings & $\begin{array}{l}0.0191^{* * *} \\
(0.003)\end{array}$ & $\begin{array}{l}0.0209^{* * *} \\
(0.004)\end{array}$ & $\begin{array}{l}0.0245^{* * *} \\
(0.005)\end{array}$ & $\begin{array}{l}0.0296^{* * *} \\
(0.005)\end{array}$ \\
\hline Tangible Assets & $\begin{array}{l}-0.0032^{*} \\
(0.002)\end{array}$ & $\begin{array}{l}-0.0004 \\
(0.002)\end{array}$ & $\begin{array}{l}0.0028 \\
(0.003)\end{array}$ & $\begin{array}{l}-0.0032 \\
(0.003)\end{array}$ \\
\hline Leverage & $\begin{array}{l}-0.0200^{* * *} \\
(0.001)\end{array}$ & $\begin{array}{l}-0.0162^{* * *} \\
(0.001)\end{array}$ & $\begin{array}{l}-0.0129^{* * *} \\
(0.002)\end{array}$ & $\begin{array}{l}-0.0068^{* * *} \\
(0.002)\end{array}$ \\
\hline Operating Income & $\begin{array}{l}0.3670^{* * *} \\
(0.005)\end{array}$ & $\begin{array}{l}0.3667^{* * *} \\
(0.006)\end{array}$ & $\begin{array}{l}0.3705^{* * *} \\
(0.006)\end{array}$ & $\begin{array}{l}0.3699^{* * *} \\
(0.007)\end{array}$ \\
\hline TFP & $\begin{array}{l}0.0149^{* * *} \\
(0.001)\end{array}$ & $\begin{array}{l}0.0181^{* * *} \\
(0.001)\end{array}$ & $\begin{array}{l}0.0234^{* * *} \\
(0.001)\end{array}$ & $\begin{array}{l}0.0288^{* * *} \\
(0.001)\end{array}$ \\
\hline Firm Size & $\begin{array}{l}-0.0049^{* * *} \\
(0.000)\end{array}$ & $\begin{array}{l}-0.0058^{* * *} \\
(0.000)\end{array}$ & $\begin{array}{l}-0.0073^{* * *} \\
(0.000)\end{array}$ & $\begin{array}{l}-0.0089^{* * *} \\
(0.000)\end{array}$ \\
\hline Year Fixed Effects & Yes & Yes & Yes & Yes \\
\hline Industry Fixed Effects & Yes & Yes & Yes & Yes \\
\hline Observations & 301,456 & 208,055 & 149,947 & 104,912 \\
\hline Log-likelihood & $-14,034$ & $-16,022$ & $-18,644$ & $-12,570$ \\
\hline Variables in First-stage Equation & $\begin{array}{l}\text { Column (1) } \\
\text { of Table } 5\end{array}$ & $\begin{array}{l}\text { Column (1) } \\
\text { of Table } 6\end{array}$ & $\begin{array}{l}\text { Column (1) } \\
\text { of Table } 7\end{array}$ & $\begin{array}{l}\text { Column (1) } \\
\text { of Table } 8\end{array}$ \\
\hline
\end{tabular}

Note: This table provides the estimates of the treatment effects model with the additional capital stock dummy and total asset growth as the dependent variables. Definitions of all variables are in the notes accompanying Tables 5, 6, 7, and 8 . The symbols *, **, and ${ }^{* * *}$ denote significance at the $10 \%, 5 \%$, and $1 \%$ levels

results for the policy variable that has a value of one if the year is after FY1999. Column (1) shows the estimation results of the probit estimation using the additional capital stock dummy as the dependent variable. The estimated coefficient of treatment $1 \times$ policy is positive and statistically significant at the $1 \%$ level, implying that treated firms increase their capital stock more after the change in the cap on capital stock that occurred under the SME Basic Act. The estimated coefficient of treatment $1 \times$ capital stock gap1 is positive and statistically significant at the $1 \%$ level. This suggests that treated firms are less likely to increase capital stock if their capital stock is close to the cap before the change in the SME Basic Act. On the other hand, the estimated coefficient of treatment $1 \times$ capital stock gap $1 \times$ policy is negative and statistically significant at the $1 \%$ level. Furthermore, the estimated marginal effect of treatment $1 \times$ capital stock gap 1 is 0.0080 , whereas that of treatment $1 \times$ capital stock gap $1 \times$ policy is -0.0115 , suggesting that the positive effects of the distance to the cap under the SME Basic Act before 1999 are insignificant after the relaxation of the cap. In sum, these results support our hypothesis that SMEs had a disincentive to graduate from SME status and increase capital stock after the change in the definitions of SMEs. The estimated coefficient of capital stock gap1 is positive and statistically significant, suggesting that all firms with a smaller gap between their capital stock and the cap increased capital stock less. Recall that under the Corporation Tax Act, the cap for SMEs is 100 million yen of capital stock, which is the same as the cap under the SME Basic Act for treatment1 before 1999. The positive coefficient of capital stock gap1 suggests that firms did not have an incentive to increase their capital stock if it is close to the cap under the Corporation Tax Act.

Column (2) shows the estimation results using the amount of $\Delta$ capital stock as the dependent variable. The estimated coefficients of treatment $1 \times$ policy and 
Table 10 Estimated results of treatment effects regression for effects of additional capital stock on debt growth

\begin{tabular}{|c|c|c|c|c|}
\hline & (1) & (2) & (3) & (4) \\
\hline \multirow[t]{2}{*}{ Additional Capital Stock Dummy } & $0.0139^{* * *}$ & $-0.0188^{* * *}$ & $-0.0479^{* * *}$ & $-0.0625^{* * *}$ \\
\hline & $(0.003)$ & $(0.004)$ & $(0.005)$ & $(0.006)$ \\
\hline \multirow[t]{2}{*}{ Cash Holdings } & -0.0029 & 0.0010 & 0.0044 & $0.0100^{*}$ \\
\hline & $(0.003)$ & $(0.004)$ & $(0.005)$ & $(0.006)$ \\
\hline \multirow[t]{2}{*}{ Tangible Assets } & $-0.0046^{* *}$ & -0.0012 & 0.0015 & -0.0027 \\
\hline & $(0.002)$ & $(0.002)$ & $(0.003)$ & $(0.004)$ \\
\hline \multirow[t]{2}{*}{ Leverage } & $-0.0178^{* * *}$ & $-0.0151^{* * *}$ & $-0.0127^{* * *}$ & $-0.0081^{* * *}$ \\
\hline & $(0.001)$ & $(0.002)$ & $(0.002)$ & $(0.002)$ \\
\hline \multirow[t]{2}{*}{ Operating Income } & $-0.2183^{* * *}$ & $-0.2181^{* * *}$ & $-0.2215^{* * *}$ & $-0.2292^{* * *}$ \\
\hline & $(0.006)$ & $(0.006)$ & $(0.007)$ & $(0.008)$ \\
\hline \multirow[t]{2}{*}{ TFP } & $0.0132^{* * *}$ & $0.0161^{* * *}$ & $0.0206^{* * *}$ & $0.0250^{* * *}$ \\
\hline & $(0.001)$ & $(0.001)$ & $(0.001)$ & $(0.001)$ \\
\hline \multirow[t]{2}{*}{ Firm Size } & $-0.0037^{* * *}$ & $-0.0048^{* * *}$ & $-0.0062^{* * *}$ & $-0.0077^{* * *}$ \\
\hline & $(0.000)$ & $(0.000)$ & $(0.000)$ & $(0.000)$ \\
\hline Year Fixed Effects & Yes & Yes & Yes & Yes \\
\hline Industry Fixed Effects & Yes & Yes & Yes & Yes \\
\hline Observations & 301,456 & 208,022 & 149,915 & 104,892 \\
\hline Log-likelihood & $-15,556$ & $-18,726$ & $-21,605$ & $-15,631$ \\
\hline \multirow[t]{2}{*}{ Variables in First-stage Equation } & Column (1) & Column (1) & Column (1) & Column (1) \\
\hline & of Table 5 & of Table 6 & of Table 7 & of Table 8 \\
\hline
\end{tabular}

Note: This table provides the estimates of the treatment effects model with the additional capital stock dummy and total debt growth as the dependent variables. Definitions of all variables are in the notes accompanying Tables 5, 6, 7, and 8 . The symbols *, **, and *** denote significance at the $10 \%, 5 \%$, and $1 \%$ levels

treatment1 $\times$ capital stock gap1 are positive and statistically significant at the $1 \%$ level. The estimated coefficient of treatment $1 \times$ capital stock gap $1 \times$ policy is negative and statistically significant at the $1 \%$ level. These results are similar to those in column (1), implying that firms increased capital stock more after the change in the definitions of SMEs. This effect is larger if a firm's capital stock is close to the cap on capital stock. Column (2) also shows the estimated coefficient capital stock gap1, which is not statistically significant. This suggests that the result for capital stock gap1 is not robust. Columns (3) and (4) show the estimation results using the policy variable that has a value of one if the year is after FY1999. The estimation results of treatment $1 \times$ policy, treatment 1 $\times$ capital stock gap1, and treatment $1 \times$ capital stock gap $1 \times$ policy are similar to those in columns (1) and (2). The results of the estimated coefficients for control variables are similar to those in Table 5, apart from those for tangible fixed assets.
Table 7 shows the estimation results using treatment2. Definitions of the dependent and control variables in each column are the same as those in Table 6. We limit observations to firms with capital stock of 30 million yen or less at the beginning of the fiscal year, which satisfy the requirements for capital stock under the SME Basic Act before 1999. Although the levels of the cap for treatment 1 and treatment 2 are different under the SME Basic Act, the estimation results are similar to those in Table 6 . The estimated coefficients of treatment $2 \times$ policy and treatment $2 \times$ capital stock gap 2 are positive and those of treatment $2 \times$ capital stock gap $2 \times$ policy are negative, and all are statistically significant at the $1 \%$ level. These results suggest that treated firms increased their capital stock less before the relaxation of the cap. In particular, these effects are larger for treated firms with capital stock that is close to the cap. After relaxing the cap in 1999, this effect was weakened. This implies that the cap set in the definitions of SMEs under the SME Basic Act 
Table 11 Estimated results of treatment effects regression for effects of additional capital stock on tangible fixed asset growth

\begin{tabular}{|c|c|c|c|c|}
\hline & (1) & (2) & (3) & (4) \\
\hline \multirow[t]{2}{*}{ Additional Capital Stock Dummy } & $0.0204^{* * *}$ & $0.0137^{* * *}$ & $0.0093^{* * *}$ & $0.0121^{* * *}$ \\
\hline & $(0.001)$ & $(0.001)$ & $(0.002)$ & $(0.002)$ \\
\hline \multirow[t]{2}{*}{ Cash Holdings } & $0.0167^{* * *}$ & $0.0155^{* * *}$ & $0.0144^{* * *}$ & $0.0166^{* * *}$ \\
\hline & $(0.001)$ & $(0.001)$ & $(0.001)$ & $(0.002)$ \\
\hline \multirow[t]{2}{*}{ Tangible Assets } & $-0.0384^{* * *}$ & $-0.0441^{* * *}$ & $-0.0474^{* * *}$ & $-0.0508^{* * *}$ \\
\hline & $(0.001)$ & $(0.001)$ & $(0.001)$ & $(0.001)$ \\
\hline \multirow[t]{2}{*}{ Leverage } & $-0.0064^{* * *}$ & $-0.0053^{* * *}$ & $-0.0047^{* * *}$ & $-0.0043^{* * *}$ \\
\hline & $(0.000)$ & $(0.001)$ & $(0.001)$ & $(0.001)$ \\
\hline \multirow[t]{2}{*}{ Operating Income } & $0.0286^{* * *}$ & $0.0258^{* * *}$ & $0.0252^{* * *}$ & $0.0242^{* * *}$ \\
\hline & $(0.002)$ & $(0.002)$ & $(0.002)$ & $(0.002)$ \\
\hline \multirow[t]{2}{*}{ TFP } & $-0.0014^{* * *}$ & $-0.0016^{* * *}$ & $-0.0016^{* * *}$ & $-0.0016^{* * *}$ \\
\hline & $(0.000)$ & $(0.000)$ & $(0.000)$ & $(0.000)$ \\
\hline \multirow[t]{2}{*}{ Firm Size } & $0.0005^{* * *}$ & $0.0005^{* * *}$ & $0.0005^{* * *}$ & $0.0007^{* * *}$ \\
\hline & $(0.000)$ & $(0.000)$ & $(0.000)$ & $(0.000)$ \\
\hline Year Fixed Effects & Yes & Yes & Yes & Yes \\
\hline Industry Fixed Effects & Yes & Yes & Yes & Yes \\
\hline Observations & 301,456 & 208,022 & 149,915 & 104,892 \\
\hline Log-likelihood & $-15,556$ & $-18,726$ & $-21,605$ & $-15,631$ \\
\hline \multirow[t]{2}{*}{ Variables in First-stage Equation } & Column (1) & Column (1) & Column (1) & Column (1) \\
\hline & of Table 5 & of Table 6 & of Table 7 & of Table 8 \\
\hline
\end{tabular}

Note: This table provides the estimates of the treatment effects model with the additional capital stock dummy and tangible fixed asset growth as the dependent variables. Definitions of all variables are in the notes accompanying Tables 5, 6, 7, and 8. The symbols ${ }^{*},{ }^{* *}$, and ${ }^{* * *}$ denote significance at the $10 \%, 5 \%$, and $1 \%$ levels

is a significant constraint on firms' additional equity capital.

Table 8 shows the estimation results using treatment3. We limit observations to firms that satisfy the requirement for capital stock under the SME Basic Act before 1999 (firms with 10 million yen or less of capital stock at the beginning of the fiscal year). The definitions of the dependent and control variables are the same as those in Table 6. Similarly to the results in Tables 6 and 7, the estimated coefficients of treatment $3 \times$ policy and treatment $3 \times$ capital stock gap 3 are positive and those of treatment $3 \times$ capital stock gap $3 \times$ policy are negative. These coefficients are statistically significant at the $1 \%$ level. These results suggest that the estimated results for the treatment and capital stock gap are robust.

The subsample of control firms includes some firms that have newly become SMEs after the policy change. Even if we use only a subsample of firms excluding these firms, the estimation results are similar to those in Tables 6, 7, and 8.

\subsection{Effects of additional equity on growth}

\subsubsection{Asset growth}

Table 9 shows the estimation results for Eq. 4 using asset growth as the dependent variable. Equation 5 in column (1) is estimated using variables in column (1) of Table 5; that in column (2) is estimated using variables in column (1) in Table 6; that in column (3) is estimated using variables in column (1) in Table 7; and that in column (4) is estimated using variables in column (1) in Table 8. The estimated coefficients in Eq. 5 are similar to the estimated results of each probit model.

The estimated results in Table 9 show that the estimated coefficients of the additional capital stock 
Table 12 Estimated results of treatment effects regression for effects of additional capital stock on inventory growth

\begin{tabular}{|c|c|c|c|c|}
\hline & $\begin{array}{l}\text { (1) } \\
\text { Growth }\end{array}$ & $\begin{array}{l}\text { (2) } \\
\text { Growth }\end{array}$ & $\begin{array}{l}\text { (3) } \\
\text { Growth }\end{array}$ & $\begin{array}{l}\text { (4) } \\
\text { Growth }\end{array}$ \\
\hline Additional Capital Stock Dummy & $\begin{array}{l}0.0060^{* * *} \\
(0.001)\end{array}$ & $\begin{array}{l}0.0030^{* * *} \\
(0.001)\end{array}$ & $\begin{array}{l}-0.0021 \\
(0.003)\end{array}$ & $\begin{array}{l}-0.0015 \\
(0.002)\end{array}$ \\
\hline Cash Holdings & $\begin{array}{l}0.0192^{* * *} \\
(0.001)\end{array}$ & $\begin{array}{l}0.0219^{* * *} \\
(0.001)\end{array}$ & $\begin{array}{l}0.0236^{* * *} \\
(0.001)\end{array}$ & $\begin{array}{l}0.0229^{* * *} \\
(0.001)\end{array}$ \\
\hline Tangible Assets & $\begin{array}{l}0.0125^{* * *} \\
(0.000)\end{array}$ & $\begin{array}{l}0.0145^{* * *} \\
(0.001)\end{array}$ & $\begin{array}{l}0.0165^{* * *} \\
(0.001)\end{array}$ & $\begin{array}{l}0.0174^{* * *} \\
(0.001)\end{array}$ \\
\hline Leverage & $\begin{array}{l}-0.0034^{* * *} \\
(0.000)\end{array}$ & $\begin{array}{l}-0.0029^{* * *} \\
(0.000)\end{array}$ & $\begin{array}{l}-0.0029^{* * *} \\
(0.000)\end{array}$ & $\begin{array}{l}-0.0029^{* * *} \\
(0.000)\end{array}$ \\
\hline Operating Income & $\begin{array}{l}0.0240^{* * *} \\
(0.001)\end{array}$ & $\begin{array}{l}0.0215^{* * *} \\
(0.001)\end{array}$ & $\begin{array}{l}0.0185^{* * *} \\
(0.001)\end{array}$ & $\begin{array}{l}0.0184^{* * *} \\
(0.002)\end{array}$ \\
\hline TFP & $\begin{array}{l}-0.0011^{* * *} \\
(0.000)\end{array}$ & $\begin{array}{l}-0.0013^{* * *} \\
(0.000)\end{array}$ & $\begin{array}{l}-0.0014^{* * *} \\
(0.000)\end{array}$ & $\begin{array}{l}-0.0008^{* * *} \\
(0.000)\end{array}$ \\
\hline Firm Size & $\begin{array}{l}0.0002^{* * *} \\
(0.000)\end{array}$ & $\begin{array}{l}0.0002^{* * *} \\
(0.000)\end{array}$ & $\begin{array}{l}0.0003^{* * *} \\
(0.000)\end{array}$ & $\begin{array}{l}0.0002^{* * *} \\
(0.000)\end{array}$ \\
\hline Year Fixed Effects & Yes & Yes & Yes & Yes \\
\hline Industry Fixed Effects & Yes & Yes & Yes & Yes \\
\hline Observations & 301,233 & 207,986 & 150,030 & 105,300 \\
\hline Log-likelihood & 406,439 & 274,842 & 192,818 & 142,635 \\
\hline Variables in First-stage Equation & $\begin{array}{l}\text { Column (1) } \\
\text { of Table } 5\end{array}$ & $\begin{array}{l}\text { Column (1) } \\
\text { of Table } 6\end{array}$ & $\begin{array}{l}\text { Column (1) } \\
\text { of Table } 7\end{array}$ & $\begin{array}{l}\text { Column (1) } \\
\text { of Table } 8\end{array}$ \\
\hline
\end{tabular}

Note: This table provides the estimates of the treatment effects model with the additional capital stock dummy and inventory growth as the dependent variables. Definitions of all variables are in the notes accompanying Tables 5, 6, 7, and 8. The symbols *, ${ }^{* *}$, and ${ }^{* * *}$ denote significance at the $10 \%, 5 \%$, and $1 \%$ levels

dummy are positive and statistically significant at the $1 \%$ level. These results are robust because we obtain similar results if we employ different variables in Eq. 5. The estimated $\rho$ is positive and statistically significant at the $1 \%$ level; the assumption of $\operatorname{corr}\left(v_{i}, \pi_{i}\right) \neq 0$ is therefore supported.

The estimated coefficients of cash holdings are positive and statistically significant at the $1 \%$ level. These results suggest that firms with high liquidity increased firm size more. The estimated coefficients of leverage are negative and statistically significant at the $1 \%$ level. Because highly leveraged firms are generally financially distressed, the performance of firms is lower if leverage is high. The coefficients of tangible assets are negative and statistically significant at the $10 \%$ level in column (1). Tangible assets are a proxy for collateral assets. We predict that the effects of tangible assets are positive on firm performance because collateral assets mitigate credit constraints for small businesses. However, this prediction is not supported by the results of Table 9. The estimated coefficients of operating income are positive and statistically significant at the $1 \%$ level. Because profitable firms have more good investment opportunities, they increase their assets more. The estimated coefficients of TFP are all positive and statistically significant at the $1 \%$ level, suggesting that firms with high productivity grow faster. The estimated coefficients of firm size are negative and statistically significant at the $1 \%$ level.

\subsubsection{Debt growth}

Table 10 shows the estimation results for Eq. 4 using debt growth as the dependent variable. The variables in the first-stage equation in each column are the same as those in Table 9. The estimated coefficients of the additional capital stock dummy are positive in column (1) and negative in columns (2)-(4). The coefficients are all statistically significant at the $1 \%$ level. The 
magnitude of the coefficients increases as the column numbers become smaller, whereas firm size (proxied by the level of capital stock) becomes smaller as the column numbers become larger. This indicates that the effects of equity issues on debt finance are positive for larger firms but negative for smaller firms. This implies that the relaxation of the capital stock constraint results in lower leverage for smaller firms. For larger firms, equity issues and debt finance are complements. In addition, our estimation results show that firms with high volatility and leverage decrease debts more after the relaxation of the capital stock requirements, allowing them to adjust their capital structure (not shown in the table).

\subsubsection{Tangible fixed asset and inventory growth}

Table 11 shows the estimation results for Eq. 4 using tangible fixed asset growth as the dependent variable. In columns (1)-(4), the estimated coefficients of the additional capital stock dummy are positive and statistically significant at the $1 \%$ level. These suggest that firms achieve capital investment by increased capital stock. Therefore, if firms near to the cap on the capital stock of the SME Basic Act decrease equity issue, firms also decrease their capital investment. Table 12 shows the estimation results using inventory growth as the dependent variable. In columns (1) and (2), the estimated coefficients of additional capital stock are positive and statistically significant at the $1 \%$ level. However, focusing on columns (3) and (4), these coefficients are not statistically significant. These results suggest that larger firms increase inventory investment by equity issue, but these results are not robust.

5.4 Magnitude of policy effects on capital stock and firm growth

\subsubsection{Additional capital stock and firm growth}

As we show in the previous subsection, firms are unlikely to increase capital stock if the level of their capital stock is near the cap of the requirement of an SME. As capital stock increases enhance the asset growth of firms, we conclude that the capital stock requirements of an SME are a significant constraint for firm growth. However, we do not show the magnitude of the distortion caused by the policy. To show the policy effects on $\Delta$ Capital Stock, we estimate the following equation.

$$
\begin{aligned}
\text { Policy }_{i, t}^{\Delta \text { CapitalStock }}= & \Delta \text { Ca } \widehat{\widehat{\text { pital Stock }}}{ }_{i, t}^{\text {Policy }} \\
& -\Delta \text { Capital Stock }{ }_{i, t}^{\text {Non-policy }} \text { (6) }
\end{aligned}
$$

$\triangle$ Capital Stock $k_{i, t}^{\text {Policy }}$ is estimated by the regression results of probit models for Eq. 3 (shown in Tables 6, 7, and 8), which is the actual trend of increase in the capital stock of SMEs. To estimate the counterfactual of the policy, we should infer the increase in capital stock if the requirements of SMEs are not changed. $\Delta$ Capital Stock ${ }_{i, t}^{\text {Non-policy }}$ is counterfactual for the increase in the capital stock. This is estimated by the regression results of probit models for Eq. 3 where Policy ${ }_{t}=0$. Policy ${ }_{i, t}$ Capital Stock is the gap between additional capital stock with and without the change in the requirement.

In addition, we estimate the magnitude of the cap on the requirement of an SME in the SME Basic Act on the asset growth of firms. To investigate this issue, we estimate the asset growth with and without the policy change as follows.

$$
\begin{aligned}
& \widehat{\text { Growt }^{\text {Policy }}}{ }_{i, t}=\hat{\gamma}_{1} \Delta \text { Capital Stock }{ }_{i, t}^{\text {Policy }} \\
& +\mathbf{Y}_{i, t} \hat{\gamma}_{2}+\hat{\mu}_{t}+\hat{v}_{i} \\
& \widehat{\text { Growt }} h_{i, t}^{\text {Non-policy }}=\hat{\gamma}_{1} \Delta \text { Capital Stock } \text { Non-policy }_{i, t}^{\text {Notal }} \\
& +\mathbf{Y}_{i, t} \hat{\gamma}_{\mathbf{2}}+\hat{\mu}_{t}+\hat{v}_{i}
\end{aligned}
$$

From these equations, we estimate Policy $y_{i, t}^{\text {Growth }}$ for each observation as follows.

$$
\begin{aligned}
& \text { Policy }_{i, t}^{\text {Growth }}= \widehat{\text { Growt }_{i, t}^{\text {Policy }}}-\widehat{\text { Growt }} h_{i, t}^{\text {Non-policy }} \\
&= \hat{\gamma}_{1}(\Delta \text { Capital Stock } \\
&-\Delta \text { Colicy } \\
&-\Delta \text { apital Stock } \\
& \text { Non-policy }
\end{aligned}
$$

$\hat{\gamma}_{i}, i=1,2, \hat{\mu}_{t}$, and $\hat{v}_{i}$ are obtained from the estimation results in Table 9. We show the average values of Policy $_{i, t}^{\Delta \text { CapitalStock }}$ and Policy $y_{i, t}^{\text {Growth }}$ for each year as the magnitude of the policy effects.

Table 13 shows the average policy effects on additional capital stock, defined by Eq. 6. Columns (1)-(3) show the policy effects for treatment 1 . We divide the sample into three groups, firms with a capital stock of $80 \mathrm{M}$ yen or less, over $80 \mathrm{M}$ to $90 \mathrm{M}$ yen, and over $90 \mathrm{M}$ to $100 \mathrm{M}$ yen. In the group of $80 \mathrm{M}$ yen or less, we cannot find any large and positive policy effects. On 


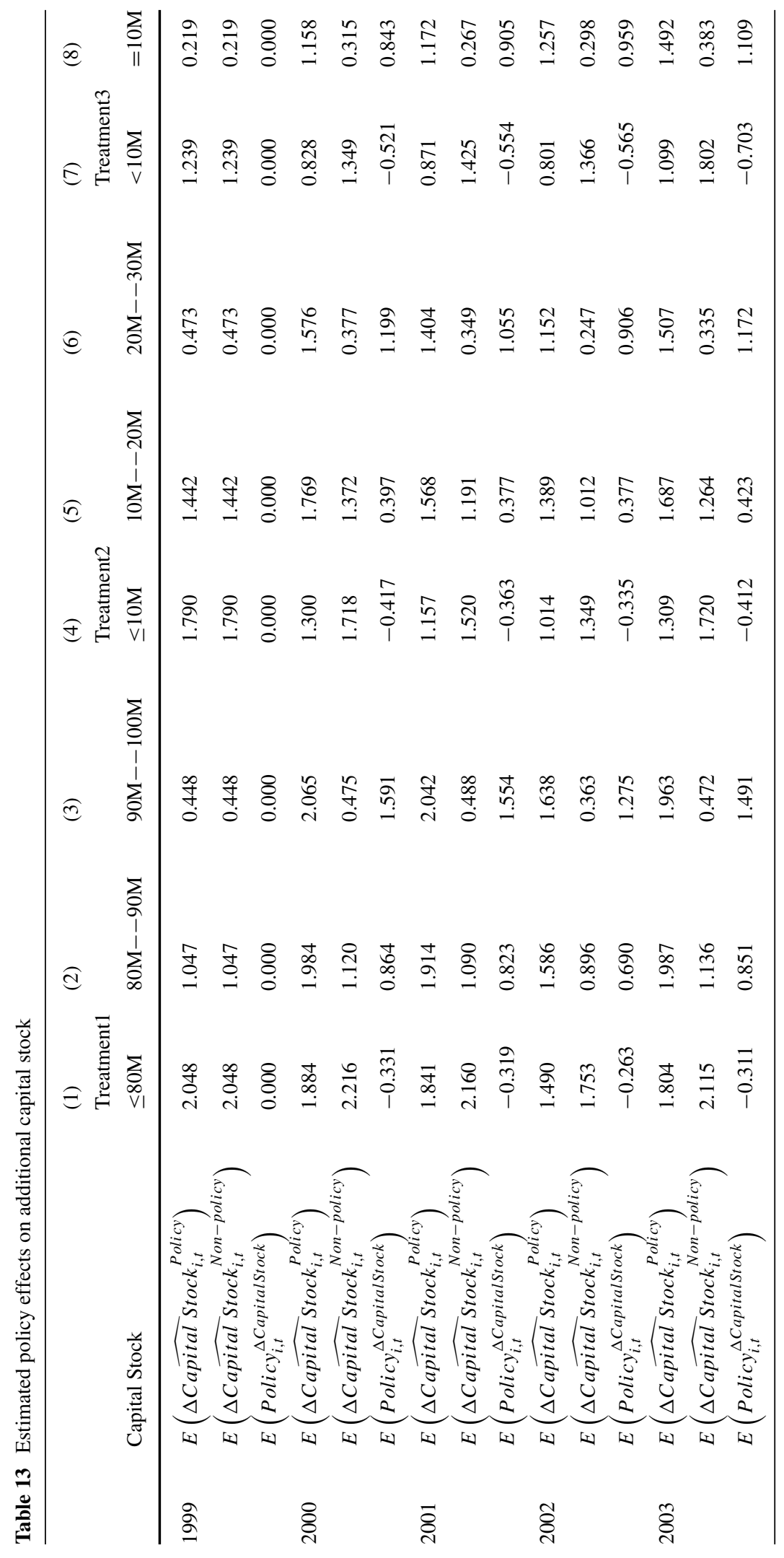




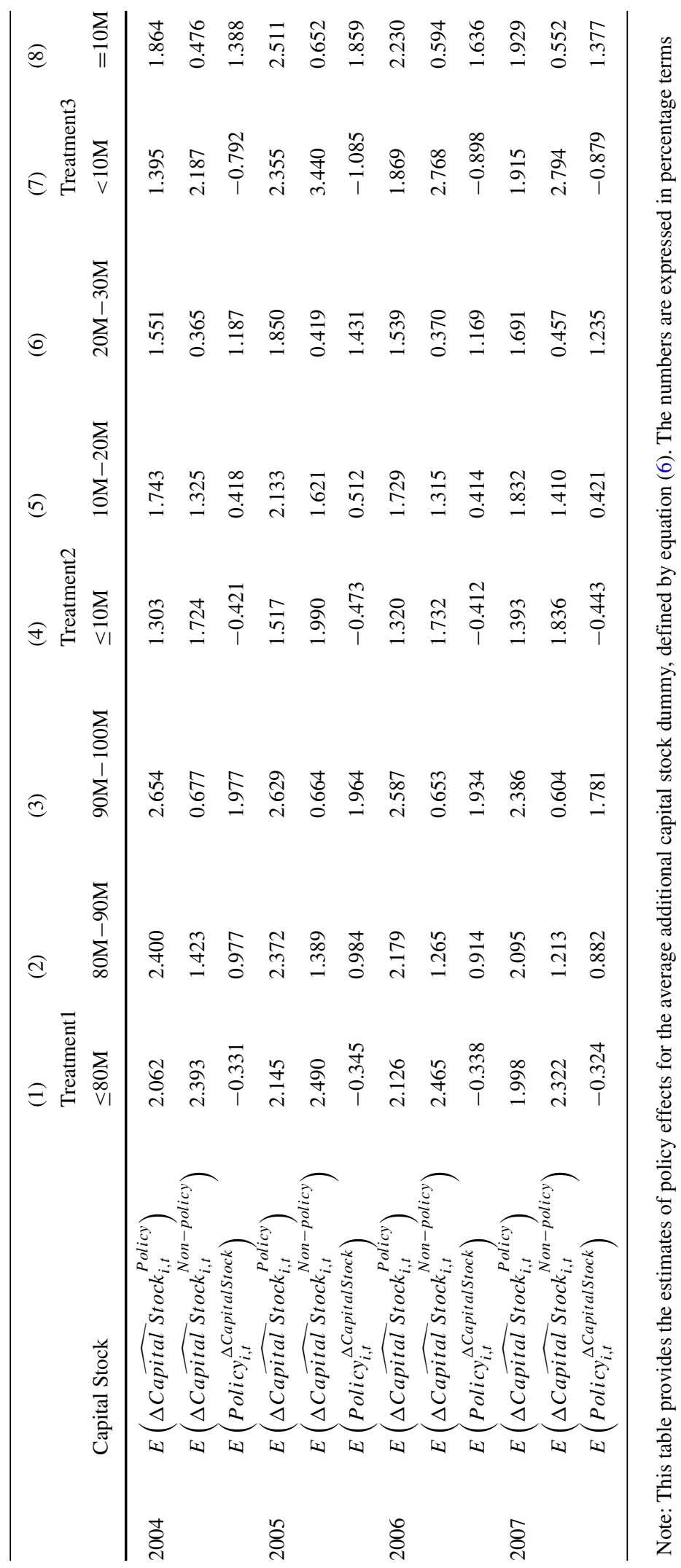




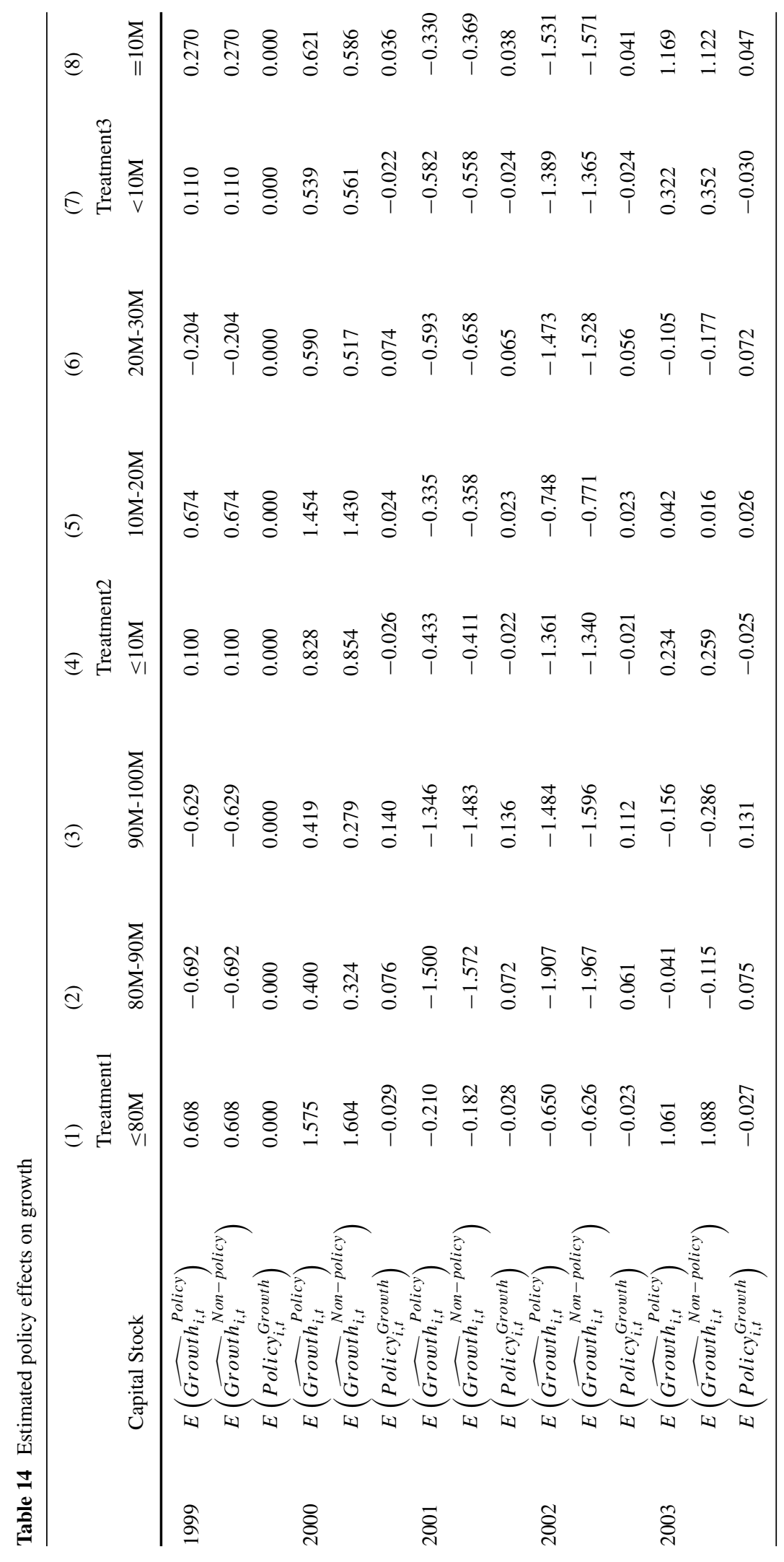




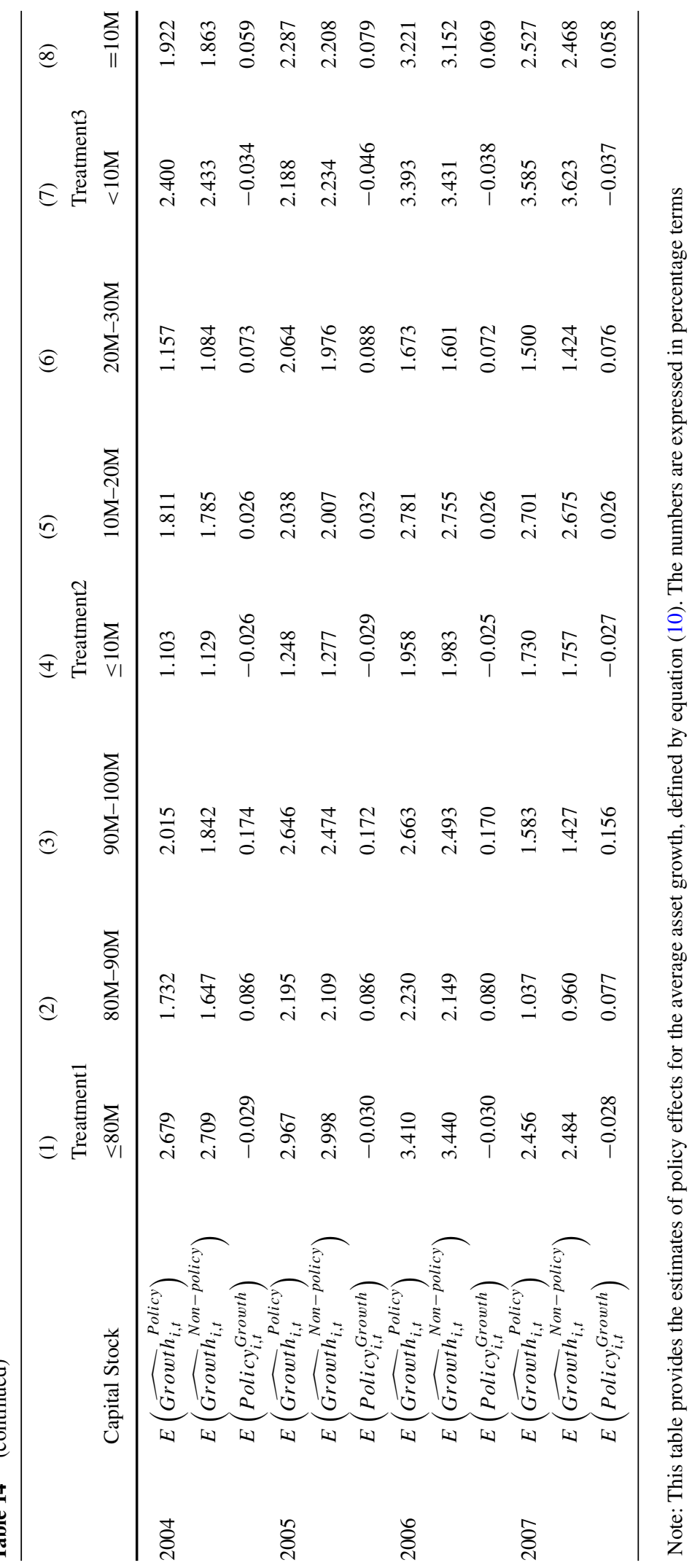




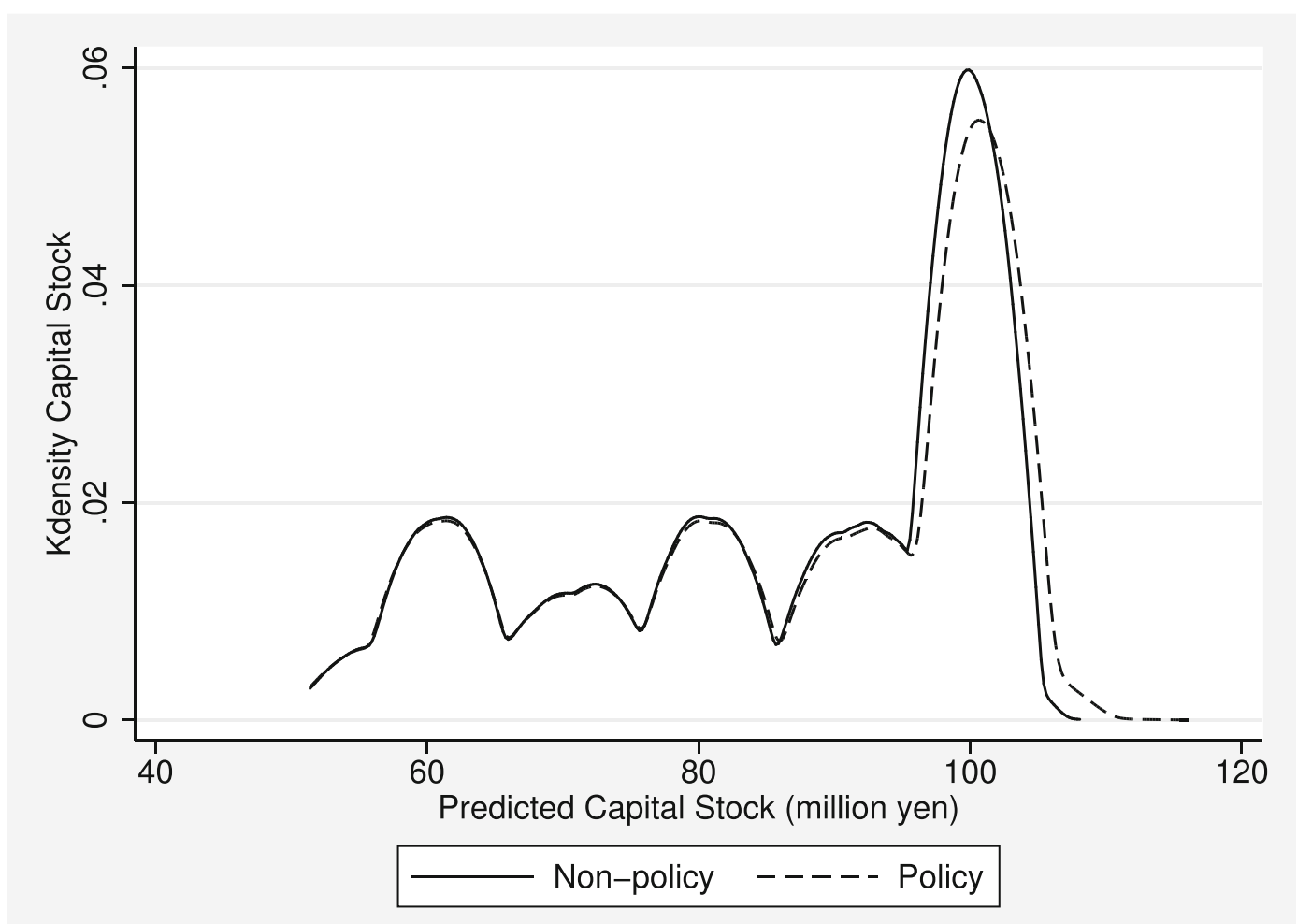

Fig. 6 Distribution of Capital Stock of Treatment1, by Kernel Density Estimation. Note: This figure shows the distribution of estimated capital stock for treatment 1 after the policy change

the other hand, focusing on firms with capital stock of over $90 \mathrm{M}$ to $100 \mathrm{M}$ yen, we see that the average effects are between 1.275 and $1.977 \%$. These firms faced the cap of capital stock requirement of the old SME Basic Act, so they were more likely to increase their capital stock after the policy change. In other words, the requirements of the SME Basic Act reduce the probability of increases in capital stock by $1.696 \%$ on average, while the actual average rate of capital stock growth is $1.885 \%$. Columns (4)-(6) show the estimation results for treatment2. Focusing on firms with a capital stock of 20-30M yen in treatment2, we see that the magnitude of the policy effects is smaller, between $0.906 \%$ and $1.431 \%$, and $1.169 \%$ on average. On the other hand, the policy effects for firms with a capital stock of $10 \mathrm{M}$ or less are negative, but the magnitude is small. Columns (7) and (8) show the estimation results for treatment 3 . The policy effects of additional capital stock for firms with $10 \mathrm{M}$ yen of capital stock are between 0.843 and $1.859 \%$. However, if we focus on the observations with capital stock less than $10 \mathrm{M}$ yen, these effects are negative. In sum, the average policy effects on additional capital stock are economically significant for firms close to the cap of the requirement of SMEs.

Table 14 shows the policy effects on firm growth, defined by Eq. 10. The format of this table is the same as that of Table 13. Columns (1)-(3) show the policy effects for treatment1. Focusing on the group for capital stock of over $90 \mathrm{M}$ to $100 \mathrm{M}$, the policy effects on asset growth are between 0.112 and $0.174 \%$, and $0.149 \%$ on average. These effects seem to be small because the numbers are around $0.15 \%$. However, the actual average asset growth rate is $1.913 \%$ from 2000 to 2007 , so the impact on the growth is not small. ${ }^{20} \mathrm{On}$ the other hand, the policy effects for firms with capital stock of $80 \mathrm{M}$ yen or less are very small, between $-0.023 \%$ and $-0.030 \%$. Focusing on the estimation results for treatment 2 in columns (4)-(6), we see that the policy effects for firms with capital stock of over $20 \mathrm{M}$ to $30 \mathrm{M}$ yen are around $0.1 \%$, which are smaller

\footnotetext{
${ }^{20}$ The low asset growth rate was caused by the financial crisis of the late 1990s.
} 


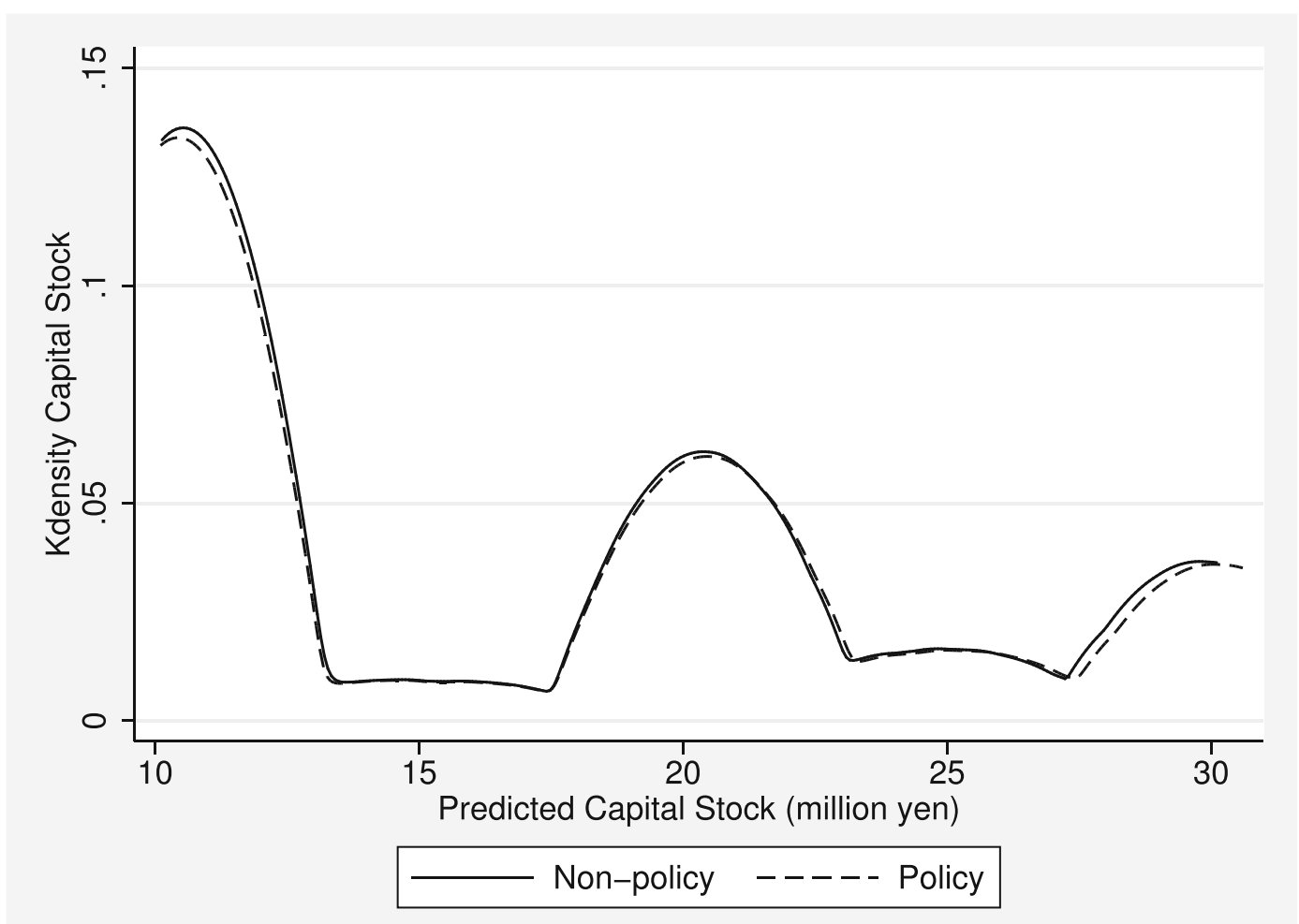

Fig. 7 Distribution of Capital Stock of Treatment2, by Kernel Density Estimation. Note: This figure shows the distribution of estimated capital stock for treatment 2 after the policy change

than those for treatment1. In the other groups, the estimated effects are negative or very small. Similarly, the effects for treatment 3 (shown in columns 7 and 8) are between 0.039 and $0.079 \%$ even if the sample is limited to firms with a capital stock equaling $10 \mathrm{M}$ yen. In sum, the policy effects on growth are positive for firms near to the cap of the requirement of SMEs. The effects are larger for treatment1, which includes larger-sized SMEs in terms of size of capital stock.

Tables 13 and 14 show that the effects on growth are small although those on the capital stock are economically significant. The reason is that firms can substitute equity capital for debt for financing investment opportunities. If the substitution effects are small, the effects on firm growth are larger than the effects estimated by our model.

\subsubsection{Distribution of capital stock}

Figures 6,7 , and 8 show the distributions of capital stock after the policy change, estimated by kernel density estimation. The value of capital stock is calculated as actual capital stock in the beginning of the fiscal year plus the estimated $\Delta$ capital stock using the tobit model shown in column (2) of Tables 6, 7, and 8 . Figure 6 shows the distribution for treatment 1 . The observations in this figure are limited to firms with a capital stock of $50 \mathrm{M}$ to $100 \mathrm{M}$ yen at the beginning of the fiscal year. We show the distributions with and without policy changes (counterfactual). The distribution peaks at $100 \mathrm{M}$ yen of capital stock, which is the cap in the old SME Basic Act and Corporate Tax Act. Comparing the distribution with and without policy changes, the distribution is right-shifted if the policy is changed. However, the peak of $100 \mathrm{M}$ yen is still large. The reason is that the cap of the Corporate Tax Act is still $100 \mathrm{M}$ yen of capital stock. Figures 7 and 8 show the distributions of capital stock with and without policy changes. To focus on the cap on the requirement of SMEs, the observations are limited to firms with capital stock of over 10M to 30M yen in Fig. 7 and those of $10 \mathrm{M}$ yen or less in Fig. 8. The distributions are right- 


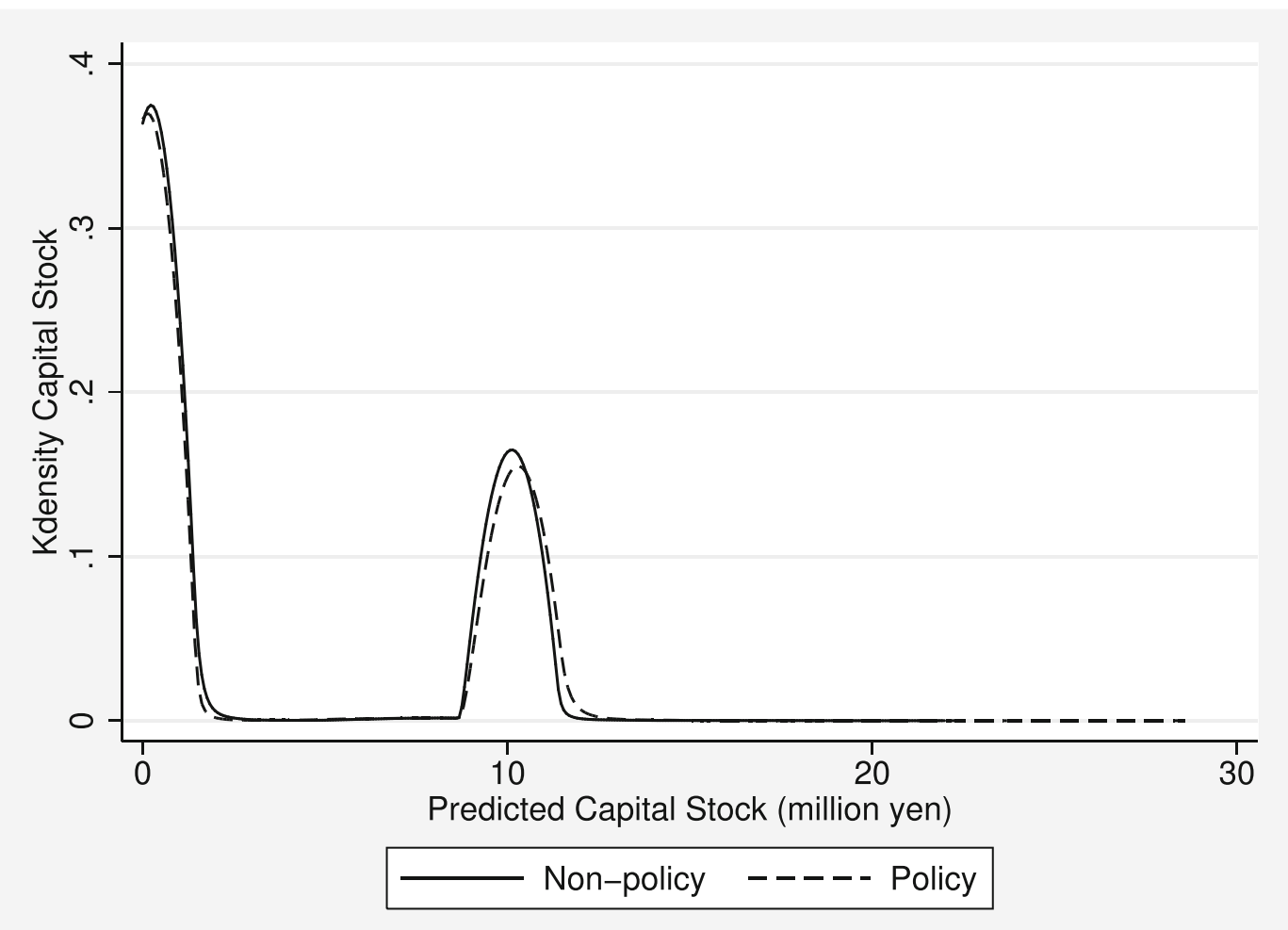

Fig. 8 Distribution of Capital Stock of Treatment3, by Kernel Density Estimation. Note: This figure shows the distribution of estimated capital stock for treatment 3 after the policy change

shifted near the cap of the requirement, suggesting that the requirement of SMEs is a cause of the distorted distribution. However, the magnitudes are not significant because the policy effects on capital stock are smaller than those for treatment 1.

These findings are consistent with the notion of Berger and Udell (1998) that shows sources of finance for SMEs divided by firm size. Small-sized firms use financial institution loans, so the equity issue is not the main source of finance. ${ }^{21}$ Therefore, the constraints on capital stock for treatment 2 and treatment 3 have smaller impacts, as shown in Figs. 7 and 8. On the other hand, Berger and Udell (1998) argue that public equity is a main source of finance for medium firms, so the constraint on capital stock for treatment 1 has a significant impact on the distribution, as shown in Fig. 6.

\footnotetext{
${ }^{21}$ Berger and Udell (1998) argue that venture capital is also a source of finance for small firms, but in Japan, venture capital is not common for SMEs.
}

\subsection{Additional test}

\subsubsection{Policy dummy}

The coefficients of the interaction variable for the treatment dummies for FY1999 and FY2000 and the policy variables are positive and statistically significant in all tables. However, we do not test whether these positive effects exist for policy dummy variables for other fiscal years. To test the other years around the changing of the SME Basic Act, we reestimate (3) including policy dummies for 5 fiscal years before and after the pseudo policy year. If the years around the change in the SME Basic Act have positive effects, the estimation results support our hypothesis for policy year dummies close to FY1999.

Table 15 shows the estimation results using policy dummies from FY1996 to FY2002. Panel A shows the estimation results using treatment1, Panel B shows those using treatment 2 , and Panel $\mathrm{C}$ shows those using treatment 3 . In all panels, the magnitude of coefficients 


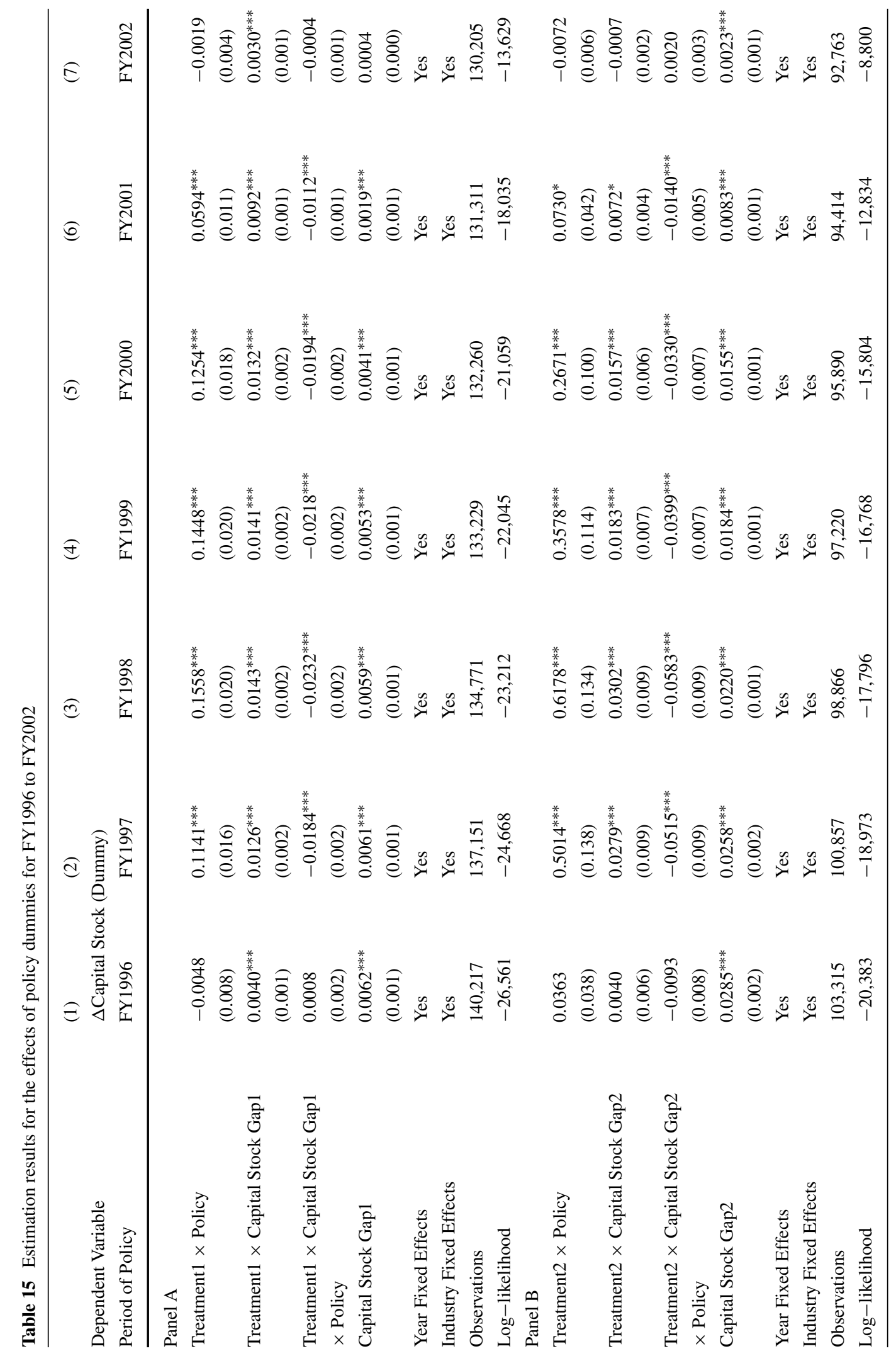




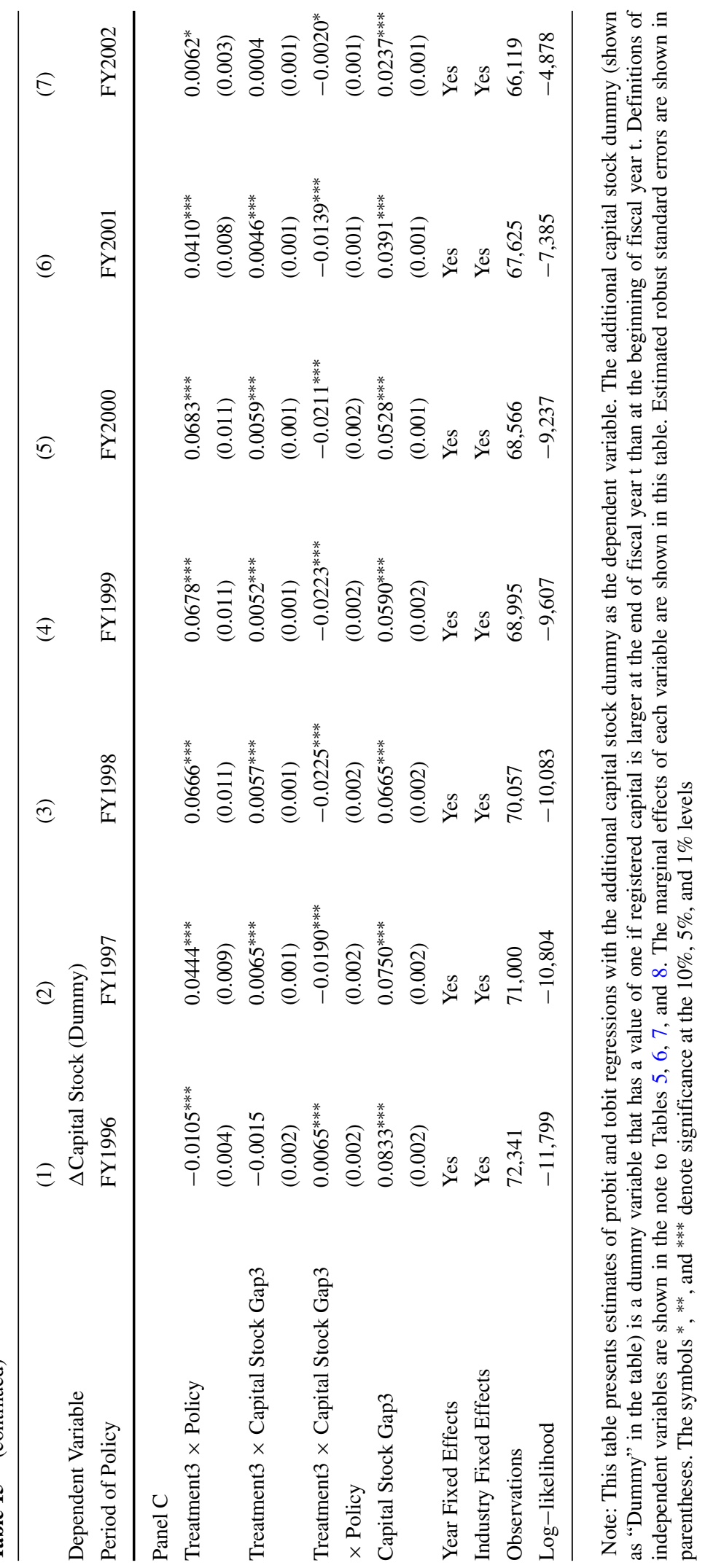




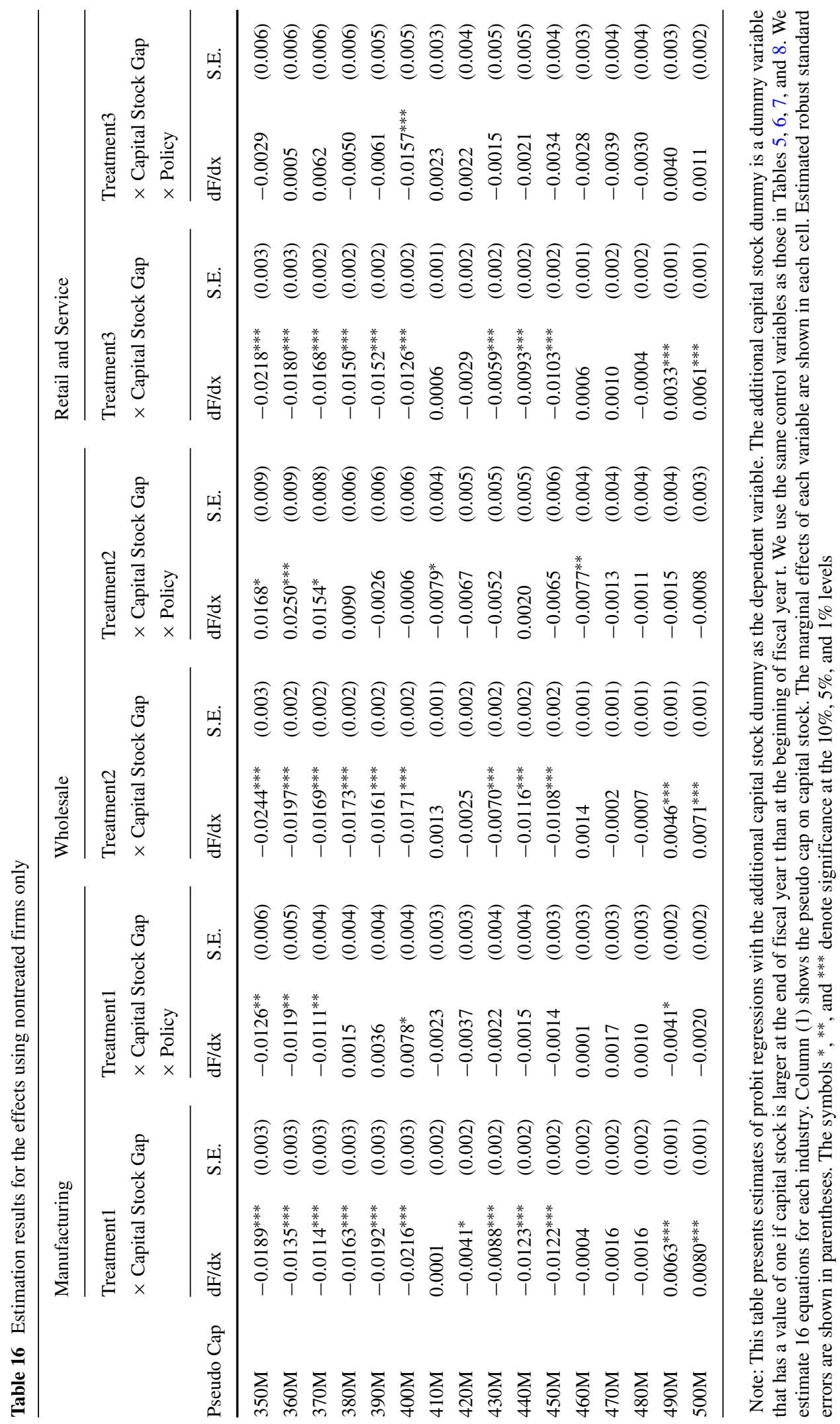


of treatment $\times$ policy, treatment $\times$ capital stock gap, and treatment $\times$ capital stock gap $\times$ policy is large around FY1999. However, focusing on FY1996 and FY2002, we see that those estimated coefficients are statistically insignificant or their magnitude is small. In sum, only the estimation results for the years around FY1999 support our hypothesis.

\subsubsection{Estimations of pseudo cap on capital stock}

In the previous section, we showed that firms whose capital stock is close to the cap of the SME Basic Act do not increase the capital stock. To show the robustness of the estimation results, we reestimate the effects of the pseudo cap on capital stock using observations of only nontreated firms. As we argued, the firms whose capital stock is under the cap of the old SME Basic Act are unaffected by the policy change. When the capital stock is between 100 and 300 million yen, firms are also affected by the policy change because they become an SME in the new SME Basic Act. Therefore, firms with capital stock of between over 300 and 500 million yen are not affected by any policy changes of the SME Basic Act. Using the subsample of firms with capital stock of between over 300 and 500 million yen, we estimate (3) using several pseudo levels of the capital stock as a proxy of the cap. We use various pseudo caps on the capital stock shown in Table 16, instead of the actual cap of the capital stock in the old SME Basic Act. As shown in Table 16, all the estimated coefficients of Treatment Tr $_{i}$ Capital Stock Gap Tit and Treatment $_{i} \times$ Capital Stock Gap $_{i, t} \times$ Policy $_{t}$ are inconsistent with the hypothesis, while the estimation results for the real cap in the SME Basic Act support the hypothesis. Therefore, the hypothesis in this paper is not supported by the untreated firms.

\section{Conclusion}

In this paper, we investigated whether firms have a disincentive to graduate from being SMEs to become large firms. To test this hypothesis, we employed two empirical strategies. First, we showed that firms with 100 million yen of capital stock were less likely to increase their capital stock. As SMEs are defined under the Corporation Tax Act and the SME Basic Act as firms with capital stock of 100 million yen or less, such firms had an incentive to meet the SME requirements and retain their SME status. Second, we showed that, after the relaxation of the definitions of SMEs under the SME Basic Act, firms were more likely to increase their capital stock. This effect is larger if a firm's capital stock is close to the cap set in the SME definition. This implies that the capital stock requirement is an effective constraint on the accumulation of additional equity capital.

We also showed that additional capital stock had positive effects on firm growth (in terms of the growth rate of a firm's total assets). As the requirements for capital stock in the definitions of SMEs had negative effects on additional capital stock, the SME requirements impeded firm growth for SMEs.

Our study has important implications for SME policies. As noted, SME policies can be important for mitigating market failure. However, the menu of SME policies adopted in Japan impedes firm growth. Governments should therefore be cautious about implementing an excessive range of policies to support SMEs.

\section{References}

Acs, Z., \& Szerb, L. (2007). Entrepreneurship, economic growth and public policy. Small Business Economics, 28(2), 109-122. https://doi.org/10.1007/s11187-006-9012-3.

Arrow, K. (1962). Economic welfare and the allocation of resources for invention. In The Rate and Direction of Inventive Activity: Economic and Social Factors. National Bureau of Economic Research, pp. 609-626.

Baumol, W.J. (1962). On the theory of expansion of the firm. The American Economic Review, 52(5), 1078-1087.

Berger, A.N., \& Udell, G.F. (1998). The economics of small business finance: The roles of private equity and debt markets in the financial growth cycle. Journal of Banking \& Finance, 22, 613-673. https://doi.org/10.1016/S03784266(98)00038-7.

Bernini, C., \& Pellegrini, G. (2011). How are growth and productivity in private firms affected by public subsidy? Evidence from a regional policy. Regional Science and Urban Economics, 41(3), 253-265. https://doi.org/10.1016/j.regsciurbeco.2011.01.005.

Cantner, U., \& Kösters, S. (2012). Picking the winner? Empirical evidence on the targeting of r\&d subsidies to start-ups. Small Business Economics, 39(4), 921-936. https://doi.org/10.1007/s11187-011-9340-9.

Cerqua, A., \& Pellegrini, G. (2014). Do subsidies to private capital boost firms' growth? A multiple regression discontinuity design approach. Journal of Public Economics, 109, 114-126. https://doi.org/10.1016/j.jpubeco.2013.11.005. 
Chaurey, R. (2017). Location-based tax incentives: evidence from India. Journal of Public Economics, 156, 101-120. https://doi.org/10.1016/j.jpubeco.2016.08.013.

Cin, B.C., Kim, Y.J., Vonortas, N.S. (2017). The impact of public R\&D subsidy on small firm productivity: evidence from Korean SMEs. Small Business Economics, 48(2), 345-360. https://doi.org/10.1007/s11187-016-9786-x.

Cowling, M. (2016). You can lead a firm to r\&d but can you make it innovate? UK evidence from SMEs. Small Business Economics, 46(4), 565-577. https://doi.org/10.1007/ s11187-016-9704-2.

Craig, B.R., Jackson, W.E., Thomson, J.B. (2007). Small firm finance, credit rationing, and the impact of SBAguaranteed lending on local economic growth. Journal of Small Business Management, 45(1), 116-132. https://doi.org/10.1111/j.1540-627X.2007.00202.x.

Czarnitzki, D., \& Delanote, J. (2015). R\&d policies for young SMEs: Input and output effects. Small Business Economics, 45(3), 465-485. https://doi.org/10.1007/s11187-0159661-1.

Dawson, C., de Meza, D., Henley, A., Arabsheibani, G.R. (2014). Entrepreneurship: Cause and consequence of financial optimism. Journal of Economics \& Management Strategy, 23(4), 717-742. https://doi.org/10.1111/jems.12076.

De Meza, D. (2002). Overlending? The Economic Journal, 112(477), F17-F31. https://doi.org/10.1111/1468-0297. 00681.

Foreman-Peck, J. (2013). Effectiveness and efficiency of SME innovation policy. Small Business Economics, 41(1), 5570. https://doi.org/10.1007/s11187-012-9426-z.

García-Santana, M., \& Pijoan-Mas, J. (2014). The reservation laws in India and the misallocation of production factors. Journal of Monetary Economics, 66, 193-209. https://doi.org/10.1016/j.jmoneco.2014.04.017.

Garicano, L., Lelarge, C., Reenen, J.V. (2016). Firm size distortions and the productivity distribution: evidence from France. American Economic Review, 106(11), 3439-79. https://doi.org/10.1257/aer.20130232.

Gourio, F., \& Roys, N. (2014). Size-dependent regulations, firm size distribution, and reallocation. Quantitative Economics, 5(2), 377-416. https://doi.org/10.3982/QE338.

Guner, N., Ventura, G., Xu, Y. (2008). Macroeconomic implications of size-dependent policies. Review of Economic Dynamics, 11(4), 721-744. https://doi.org/10.1016/j.red. 2008.01.005.

Guner, N., Ventura, G., Yi, X. (2006). How costly are restrictions on size? Japan and the World Economy, 18(3), 302-320. https://doi.org/10.1016/j.japwor.2004.11.002.

Hanson, A., \& Rohlin, S. (2011). Do location-based tax incentives attract new business establishments? Journal of Regional Science, 51(3), 427-449. https://doi.org/10.1111/ j.1467-9787.2010.00704.x.

Hosono, K., Takizawa, M., Tsuru, K. (2017). Size-dependent policy and firm growth. Discussion papers 17070, Research Institute of Economy, Trade and Industry (RIETI).

Ipinnaiye, O., Dineen, D., Lenihan, H. (2017). Drivers of SME performance: a holistic and multivariate approach. Small Business Economics, 48(4), 883-911. https://doi.org/10.1007/s11187-016-9819-5.
Kang, J.W., \& Heshmati, A. (2008). Effect of credit guarantee policy on survival and performance of SMEs in Republic of Korea. Small Business Economics, 31(4), 445-462. https://doi.org/10.1007/s11187-007-9049-y.

Koga, T. (2005). R\&d subsidy and self-financed $r \& d$ : the case of Japanese high-technology start-ups. Small Business Economics, 24(1), 53-62. https://doi.org/10.1007/s11187-0053096-z.

Lenihan, H. (2011). Enterprise Policy evaluation: is there a 'new' way of doing it? Evaluation and Program Planning, 34(4), 323-332. https://doi.org/10.1016/j.evalprogplan. 2011.03.006.

Lokshin, B., \& Mohnen, P. (2012). How effective are level-based R\&D tax credits? Evidence from the Netherlands. Applied Economics, 44(12), 1527-1538. https://doi.org/10.1080/00036846.2010.543083.

Mankiw, N.G. (1986). The allocation of credit and financial collapse. Quarterly Journal of Economics, 101(3), 455-470. https://doi.org/10.2307/1885692.

Nakata, T. (2013). Part XI amendment of the small and mediumsized enterprise basic act. In Nakata, T. (Ed.) History of japan's trade and industry policy (12): Small-and mediumsized enterprises (in Japanese). Keizai Sangyo Chosakai, Tokyo, pp. 1207-1256.

OECD (2013). SME And entrepreneurship financing: the role of credit guarantee schemes and mutual guarantee societies in supporting finance for small and mediumsized enterprises, Final Report, OECD iLibrary, Paris. https://doi.org/10.1787/f493861e-en.

OECD. (2016). Japan: Boosting growth and well-being in an ageing society. Paris: OECD iLibrary. https://doi.org/10. 1787/9789264256507-en.

Oh, I., Lee, J.-D., Heshmati, A., Choi, G.-G. (2009). Evaluation of credit guarantee policy using propensity score matching. Small Business Economics, 33(3), 335-351. https://doi.org/10.1007/s11187-008-9102-5.

Opler, T.C., \& Titman, S. (1994). Financial distress and corporate performance. Journal of Finance, 49(3), 1015-1040. https://doi.org/10.1111/j.1540-6261.1994.tb00086.x.

Ou, C., \& Haynes, G.W. (2006). Acquisition of additional equity capital by small firms - findings from the national survey of small business finances. Small Business Economics, 27(2), 157-168. https://doi.org/10.1007/s11187006-0009-8.

Saito, K., \& Tsuruta, D. (2018). Information asymmetry in small and medium enterprise credit guarantee schemes: Evidence from Japan. Applied Economics, 50(22), 24692485. https://doi.org/10.1080/00036846.2017.1400651.

Storey, D.J. (1994). Understanding the small business sector. London: Thomson Learning.

Storey, D.J. (2008). Entrepreneurship and SME policy, World Entrepreneurship Forum 2008 Edition. (available at: http://www.world-entrepreneurship-forum.com/ Publications/Articles).

Uesugi, I., Sakai, K., Yamashiro, G.M. (2010). The effectiveness of public credit guarantees in the Japanese loan market. Journal of the Japanese and International Economies, 24(4), 457-480. https://doi.org/10.1016/j.jjie.2010.08.001. 